\title{
N-Type Calcium Channels in the Developing Rat Hippocampus: Subunit, Complex, and Regional Expression
}

\author{
Owen T. Jones, ${ }^{1,2}$ Geula M. Bernstein,, ${ }^{1,2}$ Elizabeth J. Jones, ${ }^{1}$ Denis G. M. Jugloff, ${ }^{1,2}$ Marcus Law, ${ }^{1}$ \\ Wei Wong, ${ }^{1,2}$ and Linda R. Mills ${ }^{1,3}$ \\ ${ }_{1}^{1}$ Playfair Neuroscience Unit, Toronto Hospital Research Institute, Toronto Hospital Western Division, Toronto, Ontario, \\ Canada M5T 2S8, and Departments of ${ }^{2}$ Pharmacology and ${ }^{3}$ Physiology, University of Toronto, Toronto, Ontario, \\ Canada M5S $1 A 8$
}

The expression of multiple classes of voltage-dependent calcium channels (VDCCs) allows neurons to tailor calcium signaling to functionally discrete cellular regions. In the developing hippocampus a central issue is whether the expression of VDCC subtypes plays a role in key phases such as migration and synaptogenesis. Using radioligand binding and immunoblotting, we show that some N-type VDCCs exist before birth, consistent with a role in migration; however, most N-VDCC subunit expression is postnatal, coinciding with synaptogenesis. Immunoprecipitation studies indicate that the increased expression of N-VDCCs in early development occurs without subunit switching because there is no change in the fraction of $\beta_{3}$ subunits in the N-VDCC $\alpha_{1 \mathrm{~B}}-\beta_{3}$ heteromers. Fluorescence imaging of cell surface N-VDCCs during this period reveals that $\mathrm{N}$-VDCCs are expressed on somata before dendrites and that this expression is asynchronous between different subfields of the hippocampus (CA3-CA4 before CA1-CA2 and dentate gyrus). Our data argue that N-VDCC expression is an important cue in the genesis of synaptic transmission in discrete hippocampal subfields.

Key words: rat; development; hippocampus; pyramidal neurons; voltage-dependent calcium channels; subunits; dendrites; $\omega$-conotoxin
In neurons, voltage-dependent $\mathrm{Ca}^{2+}$ channels (VDCCs) orchestrate diverse functions, including neurotransmitter release (Wheeler et al., 1994; Dunlap et al., 1995; Scholz and Miller, 1995), excitability (Llinás and Sugimori, 1979; Llinás, 1988), and gene expression (Bading et al., 1993). Growing evidence indicates that VDCCs are also important in establishing the functional cytoarchitecture of the brain (Llinás and Sugimori, 1979; Mills and Kater, 1990; Vigers and Pfenninger, 1991; Komura and Rakic, 1992; Johnson and Deckwerth, 1993; Spitzer et al., 1994), but their precise role is uncertain. In situ hybridization studies have revealed mRNAs encoding VDCCs, which mediate high voltage-activated (HVA) $\mathrm{Ca}^{2+}$ currents in those regions of preand postnatal brain undergoing active proliferation and migration (Tanaka et al., 1995). In contrast, electrophysiology in vitro and in vivo suggests that neurons only express HVA currents once the cells are polarized and are no longer migrating (Peacock and Walker, 1983; Yaari et al., 1987; Reece and Schwartzkroin, 1991; Scholz and Miller, 1995). One explanation is that VDCC expression is phasic and mirrors, or even orchestrates, key developmental events (Jacobson, 1991). Unfortunately, how VDCCs might contribute to such events is complicated by their diversity.

\footnotetext{
Received March 17, 1997; revised May 18, 1997; accepted May 23, 1997.

This work was supported by grants from Natural Sciences and Engineering Research Council Canada to W.W. and L.R.M.; from Medical Research Council Canada, the Ontario Mental Health Foundation, and the Bloorview Epilepsy Program to O.T.J.; and from the Sandoz Aging Foundation to O.T.J. and L.R.M. G.M.B. was the recipient of a fellowship from the Savoy Foundation. We thank Dr. $\mathrm{V}$. Lennon for her generous gift of mAb CC18C (National Institutes of Health Grant CA-37343), C. Niesen for the Lucifer yellow fills, J. Wadia for assistance with the image analysis, and J. Francis for assistance with the microdissection.

Correspondence should be addressed to Dr. Owen T. Jones, Playfair Neuroscience Unit, Mc11-434, Toronto Hospital Research Institute, Toronto Western Hospital, 399 Bathurst Street, Toronto, Ontario, Canada M5T 2S8.

Copyright (C) 1997 Society for Neuroscience $0270-6474 / 97 / 176152-13 \$ 05.00 / 0$
}

Until recently, VDCCs were classified according to their biophysical and pharmacological characteristics into T, L, N, or P/Q subtypes. Molecular cloning, expression, and biochemical studies now show that this scheme is too simplistic (Hofmann et al., 1994; Dunlap et al., 1995). In brain, VDCCs are large (>400 kDa) heteromers composed of an $\alpha_{1}, \alpha_{2} / \delta$, and $\beta$ subunit (Wagner et al., 1988; Hell et al., 1993, 1994; Witcher et al., 1993; Hofmann et al., 1994; Leveque et al., 1994). Expression of VDCC gene products in Xenopus oocytes (Mori et al., 1991; Williams et al., 1992a) or transfected cells (Williams et al., 1992b; Fujita et al., 1993; Stea et al., 1993) shows that $\alpha_{1}$ subunits contain the ion channel pore, whereas the auxiliary $\alpha_{2} / \delta$ and $\beta$ subunits modulate optimal cell surface expression and channel kinetics (Brust et al., 1993; Castellano et al., 1993; Stea et al., 1993; Isom et al., 1994; Olcese et al., 1994). In rat brain, the $\alpha_{1}$ subunits are encoded by at least five discrete classes (A-E) of cDNA. Although $\alpha_{1 \mathrm{~A}}$ and $\alpha_{1 \mathrm{~B}}$ correspond to $\mathrm{P} / \mathrm{Q}-$ and N-VDCCs, respectively (Westenbroek et al., 1992, 1995; Witcher et al., 1993; Hell et al., 1994; Stea et al., 1994), the $\alpha_{1 \mathrm{C}}$ and $\alpha_{1 \mathrm{D}}$ classes form L-type VDCCs (Hell et al., 1993). Further diversity of VDCCs arises through multiple genes encoding the $\beta$ subunits and, in many cases, alternative splicing of the $\alpha_{1}$ and $\beta$ RNA transcripts (Hofmann et al., 1994; Dunlap et al., 1995). In contrast, $\alpha_{2} / \delta$ subunits exist as single splice variants in rat brain (Kim et al., 1992). What function does such diversity serve? Expression studies indicate that the precise complexion of gene products in the $\alpha_{1}, \alpha_{2} / \delta$, and $\beta$-VDCC heteromers defines their pharmacology and biophysical characteristics (Hofmann et al., 1994; Dunlap et al., 1995). However, specific VDCC subtypes also have unique patterns of expression in discrete brain regions and even within individual neurons (Jones et al., 1989; Robitaille et al., 1990; Westenbroek et al., 1990, 1992, 1995; Cohen et al., 1991; Hell et al., 1993; Haydon et 
al., 1994; Mills et al., 1994; Elliott et al., 1995). Thus, neurons may exploit VDCC diversity to tailor voltage-dependent $\mathrm{Ca}^{2+}$ influx in discrete functional compartments (Elliott et al., 1995). Consequently, we hypothesize that changes in functional demand experienced by developing neurons could be reflected in the dynamics of specific VDCC complex expression.

We now provide a comprehensive analysis of the expression of the neuron-specific N-type VDCC from embryonic to adult stages in rat hippocampus. This VDCC has important roles in neurotransmitter release (Robitaille et al., 1990; Cohen et al., 1991; Haydon et al., 1994; Wheeler et al., 1994; Dunlap et al., 1995; Scholz and Miller, 1995), dendritic function (Mills et al., 1994), and neuronal migration (Komura and Rakic, 1992). Via expression (Dubel et al., 1992; Williams et al., 1992b; Brust et al., 1993; Fujita et al., 1993; Stea et al., 1993) and biochemical studies (Wagner et al., 1988; Westenbroek et al., 1992; Witcher et al., 1993; Leveque et al., 1994; Scott et al., 1996), it seems that most $\mathrm{N}-\mathrm{VDCCs}$ in adult brain are $\alpha_{1 \mathrm{~B}}, \alpha_{2} / \delta$, and $\beta_{3}$ heteromers, although subpopulations containing $\beta_{1}$ or $\beta_{4}$ rather than $\beta_{3}$ subunits also may exist (Scott et al., 1996). Using site-directed antibodies and selective fluorescent and radioactive labels, we have found that our data support a significant role for N-VDCCs in the development of the nervous system.

\section{MATERIALS AND METHODS}

Synthetic peptides. Peptides corresponding to residues $852-868$ of the $\alpha_{1 \mathrm{~B}}$ (Dubel et al., 1992) sequence (GenBank accession number M92905) and residues $1-15$ of the $\beta_{3}$ (Castellano et al., 1993) sequence (GenBank accession number M88751), plus a $\mathrm{C}$-terminal cysteine for coupling, were synthesized by Vetrogen (London, Ontario, Canada). The identity of the peptides was confirmed by amino acid analysis and mass spectroscopy $\left[(\mathrm{M})+2, m / z=1017\right.$ and $(\mathrm{M})+1, m / z=1829$ for the $\alpha_{1 \mathrm{~B}}$ and $\beta_{3}$ peptides, respectively].

Preparation of antibodies. Peptides were coupled to keyhole limpet hemocyanin with the heterobifunctional cross-linker $m$-maleimidobenzoyl- $N$ hydroxysulfosuccinimide ester (sulfo-MBS; Pierce, Rockford, IL), and the conjugates were dialyzed against PBS. After New Zealand White rabbits were immunized with the conjugates (Division of Comparative Medicine, University of Toronto), antisera were collected and the $\mathrm{IgG}$ fraction was enriched by using MAPS affinity chromatography (Bio-Rad, Mississauga, Ontario, Canada). Throughout, antisera were characterized by ELISA and immunoblotting (see below).

Membrane preparation. Cortical membranes were prepared (Jones and So, 1993) from Wistar rats (timed-pregnant; Harlan Sprague Dawley, Indianapolis, IN) at E16, E18, and postnatal (P) days 0 (birth), 1.5, 2.5, $4,6,10,16,25$, and 40 . Hippocampal membranes were prepared likewise except that E16 tissue was omitted because of the lack of definition (Altman and Bayer, 1990a-c; Jacobson, 1991). All membranes were frozen and stored in liquid $\mathrm{N}_{2}$. To provide adequate tissue, we separated animals younger than P2.5 into three groups ( $>3$ pups/group) according to littermate.

Determination of N-type calcium channels. N-VDCCs were determined by radioligand binding with ${ }^{125} \mathrm{I}$-labeled $\omega$-conotoxin $\left(\left[{ }^{125} \mathrm{I}\right] \omega\right.$-CgTx $)$ (81.4 TBq/mmol; DuPont NEN, Boston, MA) (Cruz and Olivera, 1986; Jones and So, 1993; Mills et al., 1994). In developmental binding assays membranes from at least three separate animals $(>\mathrm{P} 2.5)$ or groups of animals $(<\mathrm{P} 2.5$; see above $)$ were analyzed. Specific binding was determined by subtracting nonspecifically bound radioactivity (defined as that in the presence of $1 \mu \mathrm{M}$ unlabeled $\omega \mathrm{CgTx})$ from total bound radioactivity.

Solubilization and immunoprecipitation. Membranes were radiolabeled with $\left[{ }^{125} \mathrm{I}\right] \omega$-CgTx $(12.5 \mathrm{kBq} / \mathrm{mg}$ membrane protein $), 1 \mathrm{~nm}$ final concentration, in buffer A [10 mM HEPES-NaOH, pH 7.4, 0.1 M NaCl, and 0.2 $\mathrm{mg} / \mathrm{ml} \mathrm{BSA}$ plus fresh protease inhibitors $(0.75 \mathrm{~mm}$ benzamidine and 0.1 $\mathrm{mm}$ PMSF)] for $15 \mathrm{~min}$ at $22^{\circ} \mathrm{C}$. The mixture was centrifuged at $100,000 \times g$ for $45 \mathrm{~min}$ at $4^{\circ} \mathrm{C}$ to separate bound and free label, and the pellet was solubilized (at $1 \mathrm{mg} / \mathrm{ml}$ protein) by resuspension in $10 \mathrm{~mm}$ HEPES-NaOH, pH 7.4, $1.0 \mathrm{M} \mathrm{NaCl}$, and $1 \%$ (w/v) digitonin (Wako Chemicals, Neuss, Germany) plus fresh protease inhibitors for $45 \mathrm{~min}$ at $4^{\circ} \mathrm{C}$. After centrifuging $\left(100,000 \times g\right.$ for $45 \mathrm{~min}$ at $\left.4^{\circ} \mathrm{C}\right)$ to remove insoluble material, the solubilized membranes were diluted 10 -fold with buffer A. Immunoprecipitations were performed by mixing protein Aagarose (or streptavidin-agarose for biotinylated $\alpha_{1 \mathrm{~B}}$ antibodies) preequilibrated in buffer $\mathrm{D}$ [buffer A containing $0.1 \%(\mathrm{w} / \mathrm{v})$ digitonin] with the appropriate antiserum for $6 \mathrm{hr}$ at $4^{\circ} \mathrm{C}$. The protein A-agaroseantibody complexes (100 $\mu \mathrm{l}$ of $50 \%$ slurry) were mixed with the labeled solubilizate and rocked gently for $12 \mathrm{hr}$ at $4^{\circ} \mathrm{C}$. Immune complexes were harvested by centrifugation and washed three times with a 20 -fold excess of buffer $\mathrm{D}$, and then the radioactivity in the pellets was determined by gamma counting. For competition analysis the primary antisera were incubated with the appropriate peptides ( $25 \mu \mathrm{M}$ in blocking solution) for at least $45 \mathrm{~min}$.

Gel electrophoresis and immunoblotting. Protein samples were heated in SDS sample buffer containing $\beta$-mercaptoethanol $\left(\alpha_{2} / \delta\right.$ and $\beta_{3}$ blots $)$ or dithiothreitol ( $\alpha_{1 \mathrm{~B}}$ blots), and the proteins were resolved by electrophoresis on 5 or $7.5 \%$ SDS-polyacrylamide gels (Laemmli, 1970). The proteins were transferred electrophoretically to nitrocellulose $(0.45 \mu \mathrm{m}$; Towbin et al., 1979), blocked in Tris-buffered saline (TBS) containing 5\% (w/v) nonfat dried milk, and probed with the appropriate MAPS-purified antibodies diluted in blocking solution (anti- $\alpha_{1 \mathrm{~B}}, 2-8 \mu \mathrm{g} / \mathrm{ml}$; anti- $\beta_{3}, 1-4$ $\mu \mathrm{g} / \mathrm{ml} ;$ anti- $\left.\alpha_{2} / \delta, 1: 2000\right)$. After washing in $3 \times$ TTBS [TBS containing $0.05 \%(\mathrm{v} / \mathrm{v})$ Tween-20] and $3 \times$ TBS (15 min/wash), the blots were treated with the appropriate secondary antibodies conjugated to horseradish peroxidase (1:4000-12,000; in blocking solution). After $2 \mathrm{hr}$ the blots were rewashed and immunoreactive proteins were detected by enhanced chemiluminescence (ECL; Amersham, Oakville, Ontario, Canada). To confirm competition by peptides, we routinely exposed blots overnight. Densitometric analysis of films was performed with a Bio-Rad Model GS-670 imaging densitometer. Molecular weights were determined with prestained markers (Kaleidoscope, Bio-Rad).

Confocal imaging of $N$-type calcium channels in brain slices. Hippocampal slices, $200-250 \mu \mathrm{m}$ thick, were sectioned from E18 to adult Wistar rats in ice-cold artificial cerebrospinal fluid (ACSF) solution (in mM): 124 $\mathrm{NaCl}, 26 \mathrm{NaHCO}_{3}, 3 \mathrm{KCl}, 1.25 \mathrm{Na}_{2} \mathrm{HPO}_{4}, 2 \mathrm{CaCl}_{2}, 2 \mathrm{MgCl}_{2}$, and 10 D-glucose. After incubating in ACSF bubbled with $95 \% \mathrm{O}_{2} / 5 \% \mathrm{CO}_{2}$ for $1 \mathrm{hr}$ at $20^{\circ} \mathrm{C}$, individual sections were treated for $30-45 \mathrm{~min}$ with $1.0 \mu \mathrm{M}$ $\omega$-CgTx or $0.5-1.0 \mu \mathrm{M}$ monofluoresceinated $\omega$-CgTx (Fl- $\omega$-CgTx) prepared and purified as described previously (Mills et al., 1994) in ACSF bubbled with $95 \% \mathrm{O}_{2} / 5 \% \mathrm{CO}_{2}$ at or below room temperature. Then slices were rinsed in ACSF, fixed overnight in $4 \%$ paraformaldehyde, dehydrated, cleared in methylsalicylate, and mounted in Mowiol. Individual pyramidal neurons in Fl- $\omega$-CgTx-labeled slices were outlined by filling with the intracellular dye Lucifer yellow (0.1\% in ACSF; Molecular Probes, Eugene, OR) introduced through patch-clamp electrodes (Mills et al., 1994) before fixation. Labeled slices were viewed with an inverted scanning confocal microscope (Bio-Rad MRC-600) equipped with an argon ion laser (ILT), using the fluorescein filter set and either fluor $(10 \times$ and $20 \times)$ or planapo $(60 \times)$ objectives, as detailed earlier (Mills et al., 1994). Lucifer yellow fills were visualized by identical optics. Digitized images were cropped, and in some cases colorized, using Photoshop 3.0 software (Adobe Systems, Mountainview, CA) and displayed without any further manipulation.

\section{RESULTS}

\section{Ontogeny of N-VDCC complexes determined by radioligand binding}

Expression of N-VDCCs was examined first through the binding of a radioiodinated analog of the selective $\mathrm{N}$-channel ligand $\omega$-conotoxin ([ $\left.{ }^{125} \mathrm{I}\right] \omega$-CgTx) (Cruz and Olivera, 1986) to membranes from rats at different stages in development (Fig. 1). Specific binding was detected in both hippocampus and cortex even at the earliest times examined (E18 or E16, respectively). In cortical membranes, binding increased 10-fold between E16 and $\mathrm{P} 25$. From E16 to P10, binding increased at a constant rate $(0.024$ $\mathrm{pmol} / \mathrm{mg}$ per day) and thereafter slowly leveled off until it reached a plateau value $(0.55 \mathrm{pmol} / \mathrm{mg})$ at $\mathrm{P} 25$ characteristic of the adult level. Binding also increased in hippocampal membranes but in a more complex manner. Until $\mathrm{P} 6$, the rate was similar to that in E16-P10 cortex ( $0.025 \mathrm{pmol} / \mathrm{mg}$ per day). After P6, binding increased more gradually, reached a peak at P16, and thereafter showed a modest decline to adult levels. The ages at which $50 \%$ 


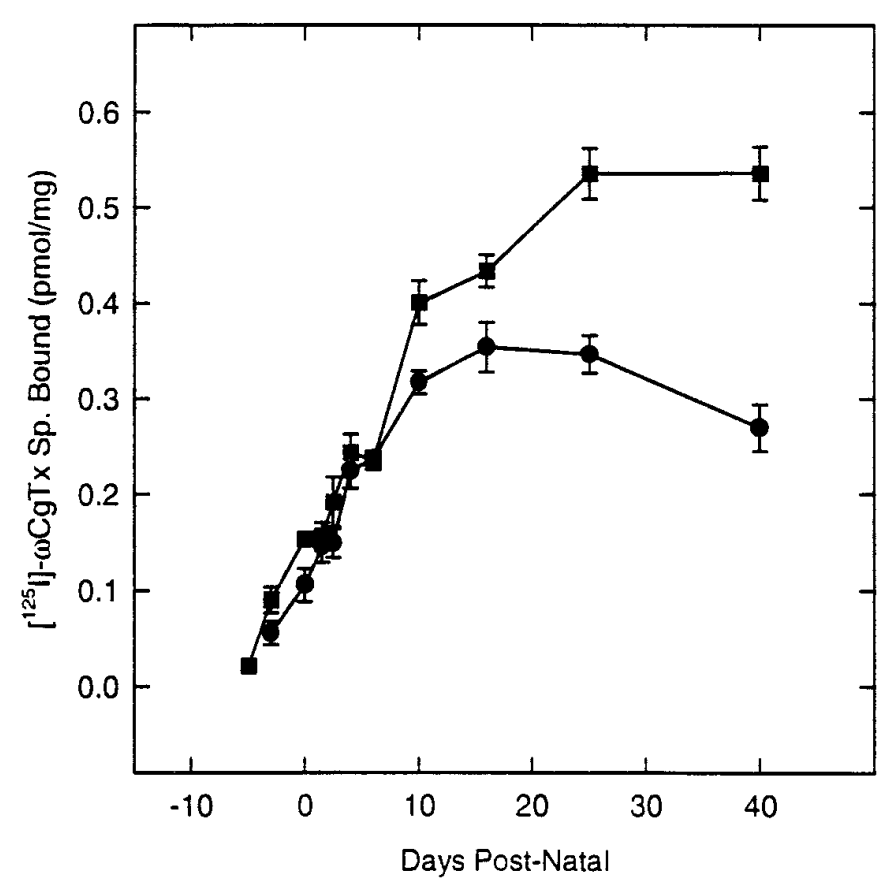

Figure 1. Expression of N-VDCCs in development determined by radioligand binding. Shown are ontogeny of $\left[{ }^{125} \mathrm{I}\right] \omega$-CgTx binding in cortical (ם) or hippocampal (๑) rat brain synaptic membranes. Values $(\mathrm{pmol} / \mathrm{mg}$ total protein) represent mean \pm SEM $(n=4)$ except for P40, in which $n=7$.

of the maximal binding $\left(E_{0.5}\right)$ seen within the first 6 weeks of birth occurred were 7.0 and $3.5 \mathrm{~d}$ for cortex and hippocampus, respectively. Direct assays of the $\left[{ }^{125} \mathrm{I}\right] \omega-\mathrm{CgTx}-\mathrm{N}-\mathrm{VDCC}$ interaction (Fig. 2) showed that these binding changes reflected developmental differences in N-VDCC density rather than toxin binding affinities. Because the $\omega$-CgTx binding assay is not a true equilibrium reaction (Jones and So, 1993), the affinities were obtained by direct assay of the kinetics of toxin association with, and dissociation from, membranes prepared from P0 and P40 hippocampi. At both $\mathrm{P} 0$ and $\mathrm{P} 40,\left[{ }^{125} \mathrm{I}\right] \omega-\mathrm{CgTx}$ binding conformed to a simple bimolecular reaction, for which the kinetics of association $\left(k_{\mathrm{on}}=3.0 \times 10^{8} 1 \cdot \mathrm{mol}^{-1} \cdot \mathrm{min}^{-1}\right.$ at $\mathrm{P} 0$ and $\left.\mathrm{P} 40\right)$ or dissociation $\left[k_{\text {off }}=5.8 \times 10^{-4} \cdot \mathrm{min}^{-1}(\mathrm{P} 0)\right.$ and $5.3 \times 10^{-4}$ $\left.\cdot \min ^{-1}(\mathrm{P} 40)\right]$ were essentially identical and gave very similar $K_{\mathrm{d}}$ values [1.9 pM (P0) and $1.8 \mathrm{pm}(\mathrm{P} 40)]$.

\section{Antibody characterization}

To resolve N-VDCC expression in detail, we raised specific polyclonal antibodies against the $\alpha_{1 \mathrm{~B}}$ and $\beta_{3}$ subunits previously shown to form the major N-VDCC complex in brain (Wagner et al., 1988; Dubel et al., 1992; Westenbroek et al., 1992; Williams et al., 1992b; Brust et al., 1993; Fujita et al., 1993; Stea et al., 1993; Witcher et al., 1993; Leveque et al., 1994; Scott et al., 1996). High-titer antisera from rabbits immunized with synthetic peptides deduced from the coding sequences of $\alpha_{1 \mathrm{~B}}$ and $\beta_{3}$ were assayed by immunoprecipitation and immunoblotting (Fig. 3). Antisera against $\alpha_{1 \mathrm{~B}}$ showed dose-dependent immunoprecipitation of up to $55 \%$ of the total $\left[{ }^{125} \mathrm{I}\right] \omega$-CgTx binding sites from detergent extracts of adult rat brain membranes (Fig. $3 A$ ). Control immunoprecipitations that used preimmune serum, $\alpha_{1 \mathrm{~B}}$ antiserum pretreated with excess competing antigenic peptide (other peptides were ineffective; data not shown), or membranes treated with excess unlabeled $\omega$-CgTx before labeling with
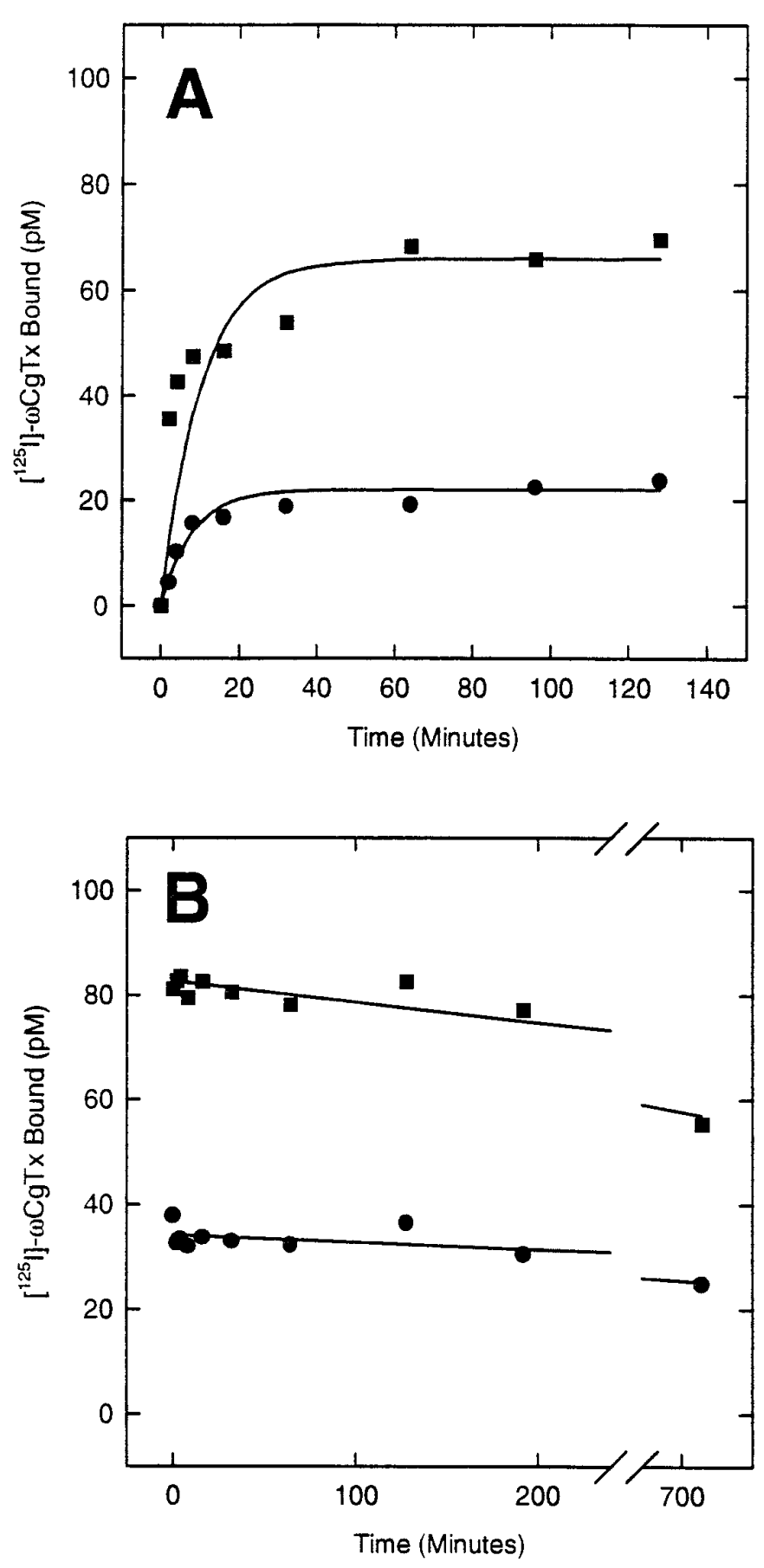

Figure 2. Kinetics of binding of $\left[{ }^{125} \mathrm{I}\right] \omega$-CgTx to hippocampal membranes from newborn (P0) or postnatal day $40(\mathrm{P} 40)$ rats. $A$, Association kinetics. $B$, Dissociation kinetics. The rates of $\left[{ }^{125} \mathrm{I}\right] \omega$-CgTx binding or dissociation were determined by filtration assays (see Materials and Methods) for membranes at P0 (@) and P40 (ם). Curves were fit assuming bimolecular reaction kinetics (see Results) and using a nonlinear leastsquares algorithm.

$\left[{ }^{125} \mathrm{I}\right] \omega$-CgTx all failed to immunoprecipitate $\left[{ }^{125} \mathrm{I}\right] \omega-\mathrm{CgTx}$ binding sites, as expected (Fig. $3 A$, inset). On immunoblots of adult rat brain, our $\alpha_{1 \mathrm{~B}}$ antibodies to a peptide within the $\alpha_{1 \mathrm{~B}}$ domain II-III linker recognized a band of approximate $M_{\mathrm{r}} 220 \mathrm{kDa}$ (Fig. $3 B$, lane 1), as reported previously (Westenbroek et al., 1992; Hell et al., 1994). This band is identical in size to that obtained with $\mathrm{mAb} \mathrm{CC} 18$, an anti-N-VDCC monoclonal antibody raised against 

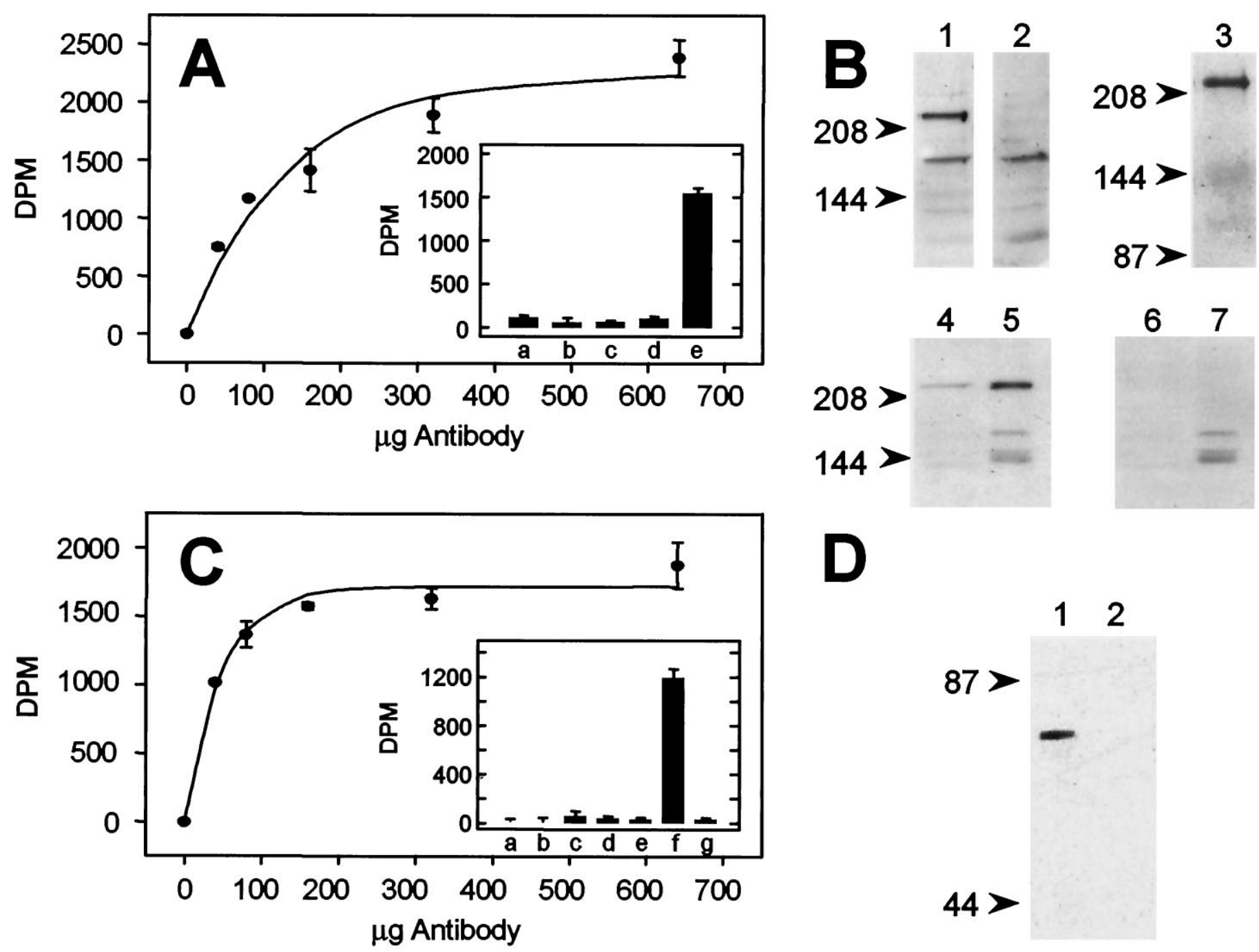

D

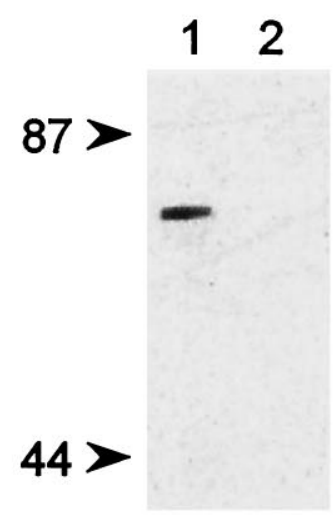

Figure 3. Characterization of $\alpha_{1 \mathrm{~B}}(A, B)$ and $\beta_{3}(C, D)$ polyclonal antibodies. $A$, Immunoprecipitation of $\left[{ }^{125} \mathrm{I}\right] \omega$-CgTx-labeled N-VDCCs by anti- $\alpha_{1 \mathrm{~B}}$ antibodies. $\left[{ }^{125} \mathrm{I}\right] \omega$-CgTx-labeled N-VDCCs were solubilized with digitonin (see Materials and Methods), and their interaction with anti- $\alpha_{1 \mathrm{~B}}$ antibodies was demonstrated by the concentration dependence of immunoprecipitation. The data were fit assuming a saturation curve of the form $y=2254 \times$ $[1-\exp (-x / 134)]$, according to Westenbroek et al. (1992), as above. The value of $2254 \mathrm{dpm}$ corresponds to $55 \%$ of the total [ $\left.{ }^{125} \mathrm{I}\right] \omega$-CgTx in each reaction. Inset, The specificity of the interaction between anti- $\alpha_{1 \mathrm{~B}}$ antibodies and solubilized $\left[{ }^{125} \mathrm{I}\right] \omega$-CgTx binding sites was determined by comparing the radioactivity in experimental immunoprecipitations $(e)$ with that in control immunoprecipitations made with preimmune serum $(a)$; control membranes, i.e., those pretreated with excess cold $\omega$-CgTx before radiolabeling $(b)$; competing antigenic peptide $(25 \mu \mathrm{M})(c)$; and preimmune serum plus competing peptide antigen $(25 \mu \mathrm{M})(d)$. B , Antibodies against $\alpha_{1 \mathrm{~B}}$ recognize a band of $\sim 220 \mathrm{kDa}$ on immunoblots (lane 1 ) and several bands of lower molecular weight. Staining of the $220 \mathrm{kDa}$, but not the minor bands, was eliminated if the antibody was treated first with competing competing $\alpha_{1 \mathrm{~B}}$ peptide antigen $(40 \mu \mathrm{M})$ (lane 2). The band recognized by our $\alpha_{1 \mathrm{~B}}$ antibodies is identical in molecular weight to that recognized by monoclonal antibodies to an $\alpha_{1 \mathrm{~B}}$ fusion protein (lane 3) (Gift of Dr. V. Lennon, Mayo Clinic, Rochester, MN), persists on purification of digitonin-solubilized N-VDCCs with heparin-agarose (lane 4 ), and is intensified after an additional wheat germ affinity chromatography step (lane 5). The $220 \mathrm{kDa}$ bands in lanes 4 and 5 both can be displaced by pretreatment of the $\alpha_{1 \mathrm{~B}}$ antibody with competing peptide (lanes 6 and 7, respectively). Blots were analyzed with MAPS-purified $\alpha_{1 \mathrm{~B}}$ antibody (10 $\mu \mathrm{g} / \mathrm{ml}$ ) and detected by ECL (see Materials and Methods). $C$, Immunoprecipitation of [ $\left.{ }^{125} \mathrm{I}\right] \omega$-CgTx-labeled N-VDCCs by anti- $\beta_{3}$ antibodies. Digitonin solubilized $\left[{ }^{125} \mathrm{I}\right] \omega-\mathrm{CgTx}$-labeled N-VDCCs immunoprecipitated as described for anti- $\alpha_{1 \mathrm{~B}}$ antibodies $(A$, above), and the data were fit to the saturation equation $y=1717 \times[1-\exp (-x / 48)]$, as above. The value $1717 \mathrm{dpm}$ corresponds to $42 \%$ of the total $\left[{ }^{125} \mathrm{I}\right] \omega-\mathrm{CgTx}$ sites in each reaction. Inset, Specificity of the $\beta_{3}$ immunoprecipitations, determined as in $A$, inset. Experimental immunoprecipitations $(f)$ were compared with the following controls: control membranes $(a)$ (see $A$, inset $b$ ), competing antigenic peptide $(25 \mu \mathrm{M})(b)$, control membranes plus competing peptide $(c)$, immunoprecipitates with no primary antibody $(d)$, control membranes and no primary antibody $(e)$, and preimmune serum $(g)$. $D$, Antibodies against $\beta_{3}$ recognize a band of $55 \mathrm{kDa}$ on immunoblots (lane 1), which can be displaced completely by competing peptide antigen (lane 2) (40 $\mu \mathrm{M})$. Molecular weights were derived from prestained molecular weight standards (arrowheads at left).

a fusion protein corresponding to the entire $\alpha_{1 \mathrm{~B}}$ II-III linker (Scott et al., 1996) (Fig. 3B, lane 3). The specificity of the $\alpha_{1 \mathrm{~B}}$ antibody was confirmed by our ability to eliminate the $220 \mathrm{kDa}$ band by pretreatment of the $\alpha_{1 \mathrm{~B}}$ antiserum with competing antigenic peptide (Fig. 3B, lane 2) and by the persistence of the 220 $\mathrm{kDa}$ band on affinity purification of N-VDCCs, using wheat germ agglutinin and heparin-agarose (Fig. 3B, lanes 4 and 5; peptide controls, lanes 6 and 7, respectively) (Westenbroek et al., 1992; Witcher et al., 1993). Antisera against $\beta_{3}$ also proved effective in selectively immunoprecipitating $\left[{ }^{125} \mathrm{I}\right] \omega$-CgTx binding sites from detergent extracts of adult rat brain membranes (Fig. $3 C$ and inset). The maximum fraction of $\left[{ }^{125} \mathrm{I}\right] \omega-\mathrm{CgTx}$ binding sites that 
could be immunoprecipitated by the $\beta_{3}$ antibodies was consistently $76 \pm 4 \%(n=5)$ of that immunoprecipitated by $\alpha_{1 \mathrm{~B}}$ antibodies. On immunoblots, our $\beta_{3}$ antibody recognized a single band of $M_{\mathrm{r}} 55 \mathrm{kDa}$ identical to that predicted from the $\beta_{3} \mathrm{cDNA}$ (Fig. 3D).

\section{Immunoblot analysis of the expression of N-VDCC subunits in hippocampal development}

The ontogeny of N-VDCC subunit proteins was determined by immunoblot analysis with anti- $\alpha_{1 \mathrm{~B}}$ and $\beta_{3}$ antibodies (Fig. 4). Although both mAb CC18 and our polyclonal $\alpha_{1 \mathrm{~B}}$ antibodies gave similar results, mAb CC18 was used because of its greater sensitivity of detection. Expression of the ubiquitous $\alpha_{2} / \delta$ subunit was examined with a commercially available monoclonal antibody to the skeletal muscle protein that cross-reacts with that in brain (Upstate Biotechnology, Lake Placid, NY). Expression of the 220 kDa $\alpha_{1 \mathrm{~B}}$ subunit (Fig. $4 A, D$ ) was detectable but very weak at E18 (the earliest stage examined), rose markedly (48-fold increase) after birth to reach a maximum at P10, and thereafter followed a slight decline to adult levels. In contrast, a phasic profile was noted for the band corresponding to the reduced form of the $\alpha_{2} / \delta$ subunit ( $M_{\mathrm{r}} 150 \mathrm{kDa}$; Gurnett et al., 1996) (Fig. 4B,E). Expression of $\alpha_{2} / \delta$ was evident as early as E18 (45\% of adult levels), waned until P4, and then rose to a plateau level at P10. The expression of $\beta_{3}$ subunits also increased markedly with development but with a profile distinct from either the $\alpha_{1 \mathrm{~B}}$ or the $\alpha_{2} / \delta$ subunits. Thus, $\beta_{3}$ subunit expression increased eightfold from birth, attained a maximum level at P25, and then declined slightly to its adult level (Fig. 4C,F).

\section{Immunoprecipitation analysis of the expression of $\alpha_{1 \mathrm{~B}}-\beta_{3} \mathrm{~N}-$ VDCC complexes in the developing hippocampus}

Although immunoblotting delineated the ontogeny of the $\alpha_{1 \mathrm{~B}}$, $\alpha_{2} / \delta$, or $\beta_{3}$ subunits, the degree of their coassembly was unclear. We therefore analyzed the extent of $\alpha_{1 \mathrm{~B}}-\beta_{3}$ complexation during development by immunoprecipitation assays of solubilized $\mathrm{N}-\mathrm{VDCCs}$. The extent of $\alpha_{1 \mathrm{~B}}-\alpha_{2} / \delta$ complexation was not examined because of poor recognition of native $\alpha_{2} / \delta$ in digitonin extracts by anti-skeletal muscle $\alpha_{2} / \delta$ antibodies, as reported elsewhere (Sakamoto and Campbell, 1991), and the possibility that $\mathrm{N}-\mathrm{VDCC}$ contain $\alpha_{2} / \delta$ isoforms that are not recognized by this antibody (Westenbroek et al., 1992). Because immunoprecipitation assays demand the use of solubilized material, we first tested for developmental differences in the ease of solubilization of $\left[{ }^{125} \mathrm{I}\right] \omega$-CgTx binding sites. Surprisingly, although the ontogeny of the $\left[{ }^{125} \mathrm{I}\right] \omega$-CgTx binding sites in each reaction (Fig. $5 A$, open bars) mirrored that in the membrane binding assays, as expected (see Fig. 1), the ontogeny of solubilized $\left[{ }^{125} \mathrm{I}\right] \omega$-CgTx binding sites (Fig. 5A, solid bars) showed a shallower profile, with a maximum at $\mathrm{P} 4$. The source of this discrepancy became apparent by examining the percentage of $\left[{ }^{125} \mathrm{I}\right] \omega$-CgTx binding sites solubilized at each developmental day. Between E18 and P10 the fraction of sites that could be solubilized declined by $40 \%$ and thereafter remained constant ( $30 \%$ for hippocampus). Thus, the developmental changes in the concentration of solubilized $\left[{ }^{125} \mathrm{I}\right] \omega$-CgTx binding sites shown in Figure $5 A$ (solid bars) reflect changes in both N-VDCC expression and solubilization. At E18, $\left[{ }^{125} \mathrm{I}\right] \omega$-CgTx binding sites are poorly expressed but readily solubilized; at later stages $\left[{ }^{125} \mathrm{I}\right] \omega$-CgTx binding sites are more prevalent but less readily solubilized.

Having defined the developmental profile for the concentration of solubilized $\left[{ }^{125} \mathrm{I}\right] \omega-\mathrm{CgTx}$ binding sites, we examined that frac- tion that could be immunoprecipitated by $\beta_{3}$ antibodies (Fig. 6A). As shown, $\left[{ }^{125} \mathrm{I}\right] \omega$-CgTx radioactivity in the $\beta_{3}$ immunoprecipitates rose from low levels at E18, peaked at P10, and then declined modestly to P25. From the similar ratio in the normalized $\beta_{3}$ immunoprecipitated and solubilized $\left[{ }^{125} \mathrm{I}\right] \omega$-CgTx binding site profiles between E18 and P25 (Fig. 6A, inset), we infer that changes in the $\alpha_{1 \mathrm{~B}}-\beta_{3}$ complexes parallel those of the entire $\mathrm{N}-\mathrm{VDCC}$ population. To examine $\alpha_{1 \mathrm{~B}}-\beta_{3}$ complexation further, we immunoprecipitated the $\beta_{3}$ subunits associated with $\left[{ }^{125} \mathrm{I}\right] \omega$ CgTx-labeled N-VDCCs, using biotinylated $\alpha_{1 \mathrm{~B}}$ antibodies bound to streptavidin-agarose. Then the $\alpha_{1 \mathrm{~B}}$ complexes were tested for associated $\beta_{3}$ subunits by immunoblotting with digoxygenylated anti- $\beta_{3}$ antibodies. The use of both biotin and digoxygenin-labeled antibodies was essential in reducing nonspecific bands from IgGs in the immunoprecipitates. As shown in Figure $6 B$, both the radioactivity corresponding to $\left[{ }^{125} \mathrm{I}\right] \omega-\mathrm{CgTx}$ binding sites and $\beta_{3}$ expression in the $\alpha_{1 \mathrm{~B}}$ immunoprecipitates have very similar developmental profiles (Fig. 6B). This was confirmed further by the similarity in the ratios of the normalized profiles for $\beta_{3}$ expression and $\left[{ }^{125} \mathrm{I}\right] \omega$-CgTx radioactivity between E18 and P25 (Fig. 6B, inset).

\section{Visualization of $\mathrm{N}$-type VDCCs on hippocampal pyramidal neurons}

To examine N-VDCC expression in intact neurons, we labeled developing brain slices selectively with Fl- $\omega-\mathrm{CgTx}$ (Mills et al., 1994). In previous studies we have shown Fl- $\omega-\mathrm{CgTx}$ to be a powerful biologically active probe of N-VDCCs, which is internalized only slowly at room temperature (Mills et al., 1994). Thus, Fl- $\omega$-CgTx labeling highlights only those N-VDCCs at the nerve cell surface - a significant advantage compared with most immunocytochemical approaches. Hippocampal brain slices sectioned at different days were labeled with Fl- $\omega$-CgTx, fixed, and visualized by laser confocal microscopy (Figs. 7, 8). Elsewhere we have shown that labeling of adult hippocampal slices by Fl- $\omega-\mathrm{CgTx}$ can be displaced completely by pretreating the slices with native $\omega$-CgTx (Mills et al., 1994). To exclude any developmental artifacts in such control experiments, we compared E18 (Fig. 7A) and P40 (Fig. 7C) hippocampal slices treated with native $\omega$-CgTx before Fl- $\omega$-CgTx labeling. In both E18 (Fig. 7B) and P40 (Fig. $7 D$ ) controls, staining was completely absent. We next examined Fl- $\omega$-CgTx labeling in hippocampal slices from E19 to adulthood (Fig. $7 E-H)$. At E19, Fl- $\omega-\mathrm{CgTx}$ labeling was barely discernible in any hippocampal subfield (Fig. 7E). However, by birth (Fig. $7 F$ ), surface expression of N-VDCCs was prevalent in the pyramidal layers of subfields CA3-CA4, the somata of the subiculum, and to a lesser extent in the external granule cell layer of the dentate gyrus and stratum radiatum of CA3-CA4. Surprisingly, staining was barely detectable in CA1-CA2 (Fig. $7 F$, asterisk) at this stage and only began to appear at $\sim \mathrm{P} 4$. This period also demarcated the onset of expression of N-VDCCs in the internal granule cell layer of the dentate gyrus ( $D G i$; Fig. $7 G)$. Once initiated, N-VDCC expression increased to adult levels (Fig. 7E) throughout all hippocampal subfields. The lack of Fl- $\omega-\mathrm{CgTx}$ labeling in the CA1 region of rats before $\mathrm{P} 4$ (Fig. $7 F$ ) did not reflect simply a lack of cells in this region, because individual CA1 neurons adjacent to the subiculum (Fig. $8 A$, inset) could be filled with the intracellular dye Lucifer yellow at P2 (Fig. $8 A$ ) or P3 (Fig. 8B). We next exploited the late onset of Fl- $\omega$-CgTx labeling in CA1 neurons to examine the spatiotemporal patterns of N-VDCC expression. Hippocampal slices again were labeled with Fl- $\omega$-CgTx, and individual cells in stratum pyramidale were 

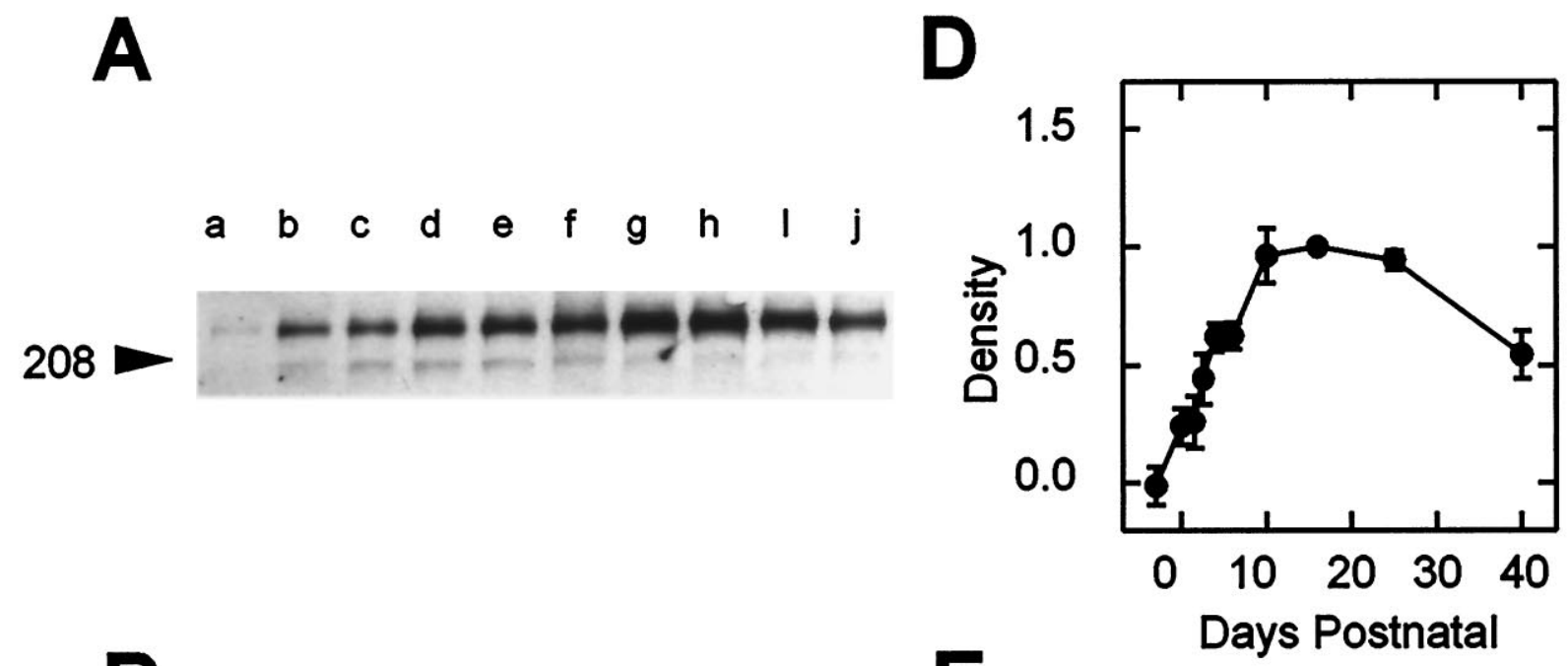

144
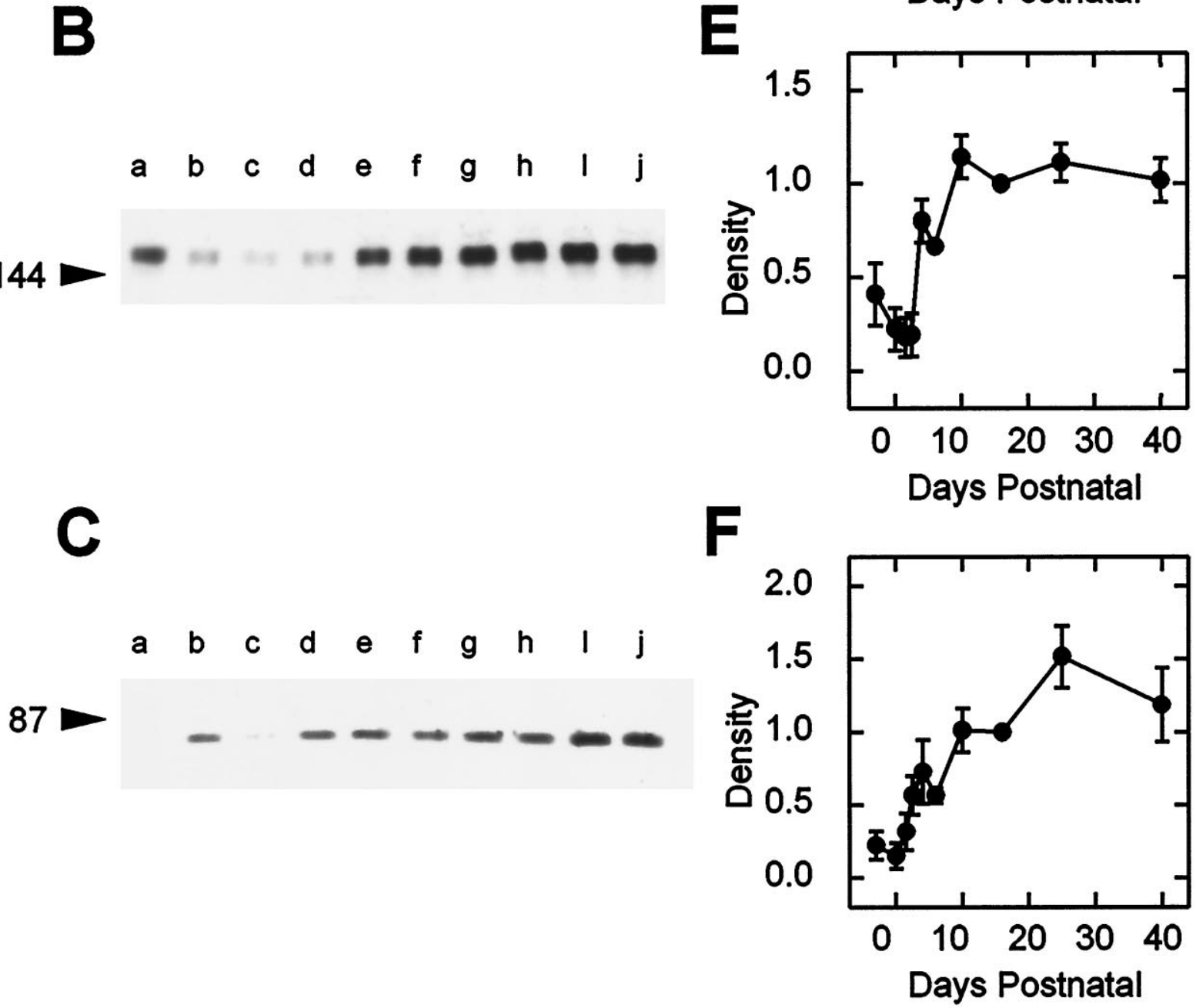

Figure 4. Ontogeny of N-VDCC subunits in hippocampal membranes as determined by immunoblotting. Immunoblots were probed with the following antibodies: $\alpha_{1 \mathrm{~B}}(A), \alpha_{2} / \delta(B)$, and $\beta_{3}(C)$ (see Materials and Methods). Lanes $a-j$ correspond to the following ages at which the hippocampal membranes were prepared: E18, P0, 1.5, 2.5, 4, 6, 10, 16, 25, and 40. Arrowheads at left denote positions of molecular weight markers (see Materials and Methods). Densitometric scans of immunoblots corresponding to $\alpha_{1 \mathrm{~B}}, \alpha_{2} / \delta$, and $\beta_{3}$ are shown in $D-F$, respectively. Each panel shows data \pm SEM obtained from three separate sets of animals, normalized to the values seen at P16.

outlined by Lucifer filling. As shown in Figure $8 C$, N-VDCC labeling in P7 CA1 neurons was confined mainly to regions containing the somata and very proximal dendrites $(<30 \mu \mathrm{m})$ despite the disclosure of exuberant dendritic arbors in these neurons by Lucifer yellow (Fig. $8 E$ ). In contrast, Fl- $\omega$-CgTx labeling of adult CA1 neurons revealed intense, often punctate, staining extending throughout the entire somatodendritic region, as detailed previously (Mills et al., 1994) (Fig. 8D). 

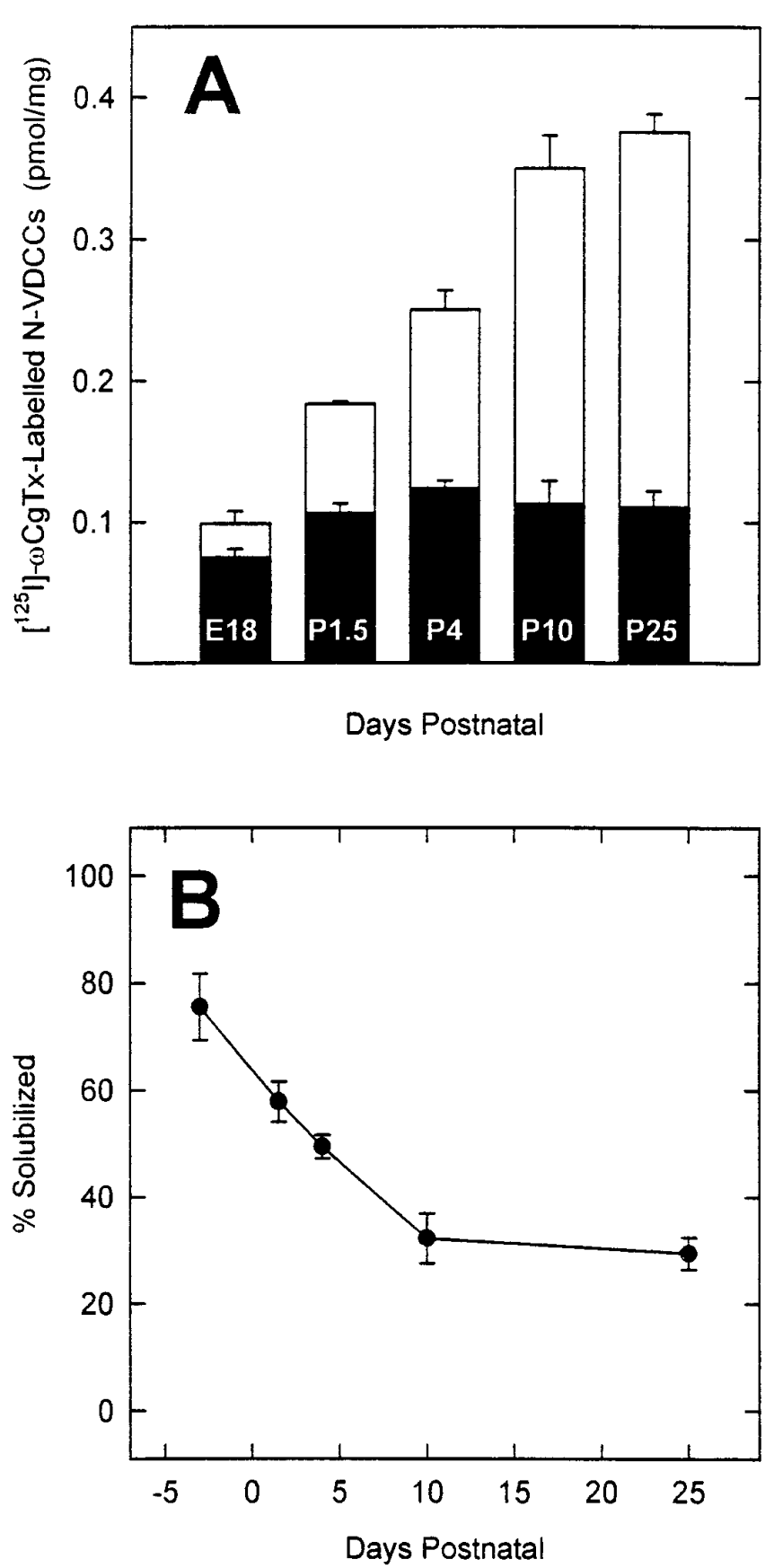

Figure 5. The extent of solubilization of hippocampal N-VDCCs changes during development. $A$, Comparison of the number of $\left[{ }^{125} \mathrm{I}\right] \omega$ $\mathrm{CgTx}$ binding sites in digitonin-treated membranes from different days in development before (open bar) and after (solid bar) centrifugation at $100,000 \times g$ for $1 \mathrm{hr}$ (see Materials and Methods). Note the different ontogeny for the solubilized (solid bar) versus the total number (open bar) of $\left[{ }^{125} \mathrm{I}\right] \omega$-CgTx binding sites. $B$, Solubilization of $\left[{ }^{125} \mathrm{I}\right] \omega-\mathrm{CgTx}$ binding sites decreases in development. In both $A$ and $B$ the data represent the mean $\pm \operatorname{SEM}(n=7)$.

\section{DISCUSSION}

We have defined the spatiotemporal expression of N-VDCCs in the hippocampus via selective ligand binding, immunoblotting of $\mathrm{N}-\mathrm{VDCC}$ subunits, subunit coupling, and fluorescent imaging of channels expressed at the cell surface. Although some $\alpha_{1 \mathrm{~B}}, \alpha_{2} / \delta$, and $\beta_{3}$ subunits are found at E18, most of their expression occurs
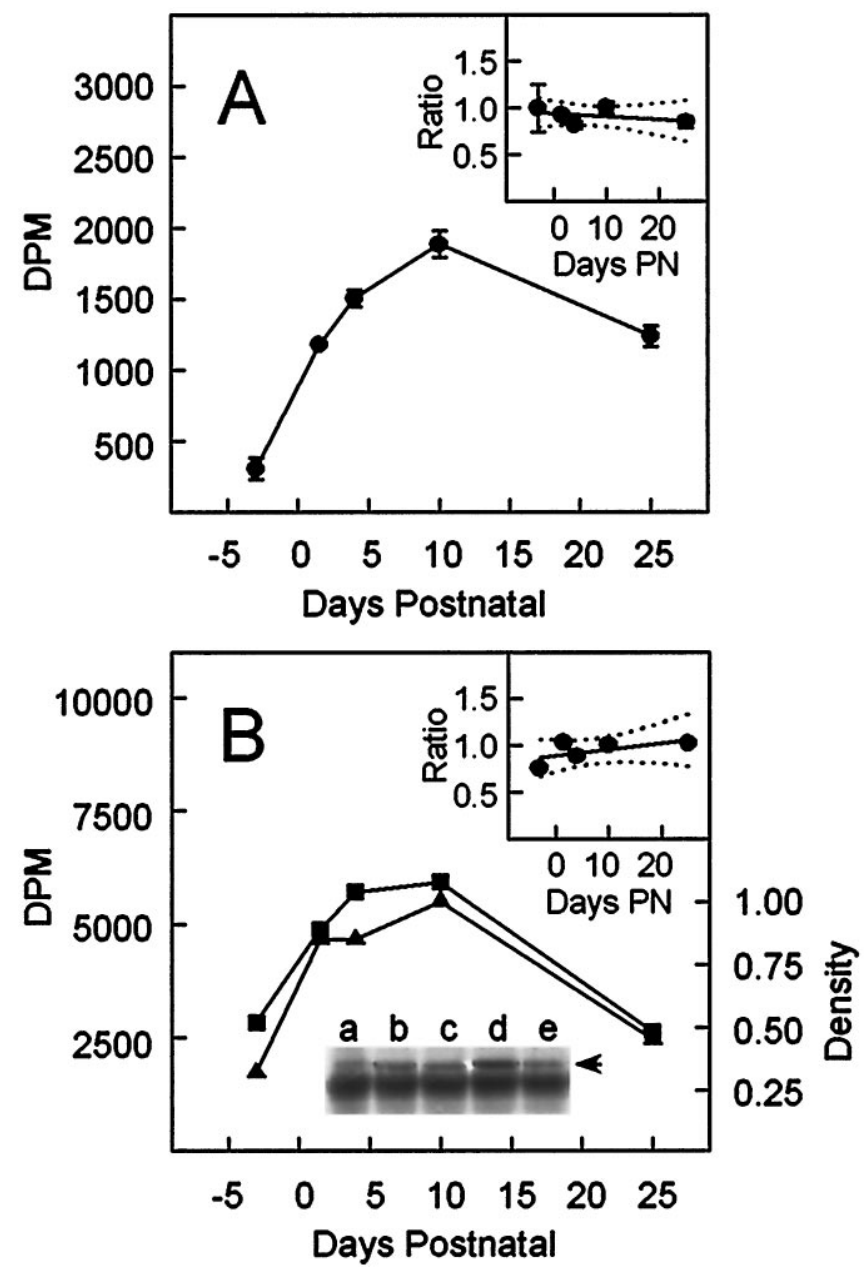

Figure 6. Immunoprecipitation analysis of $\alpha_{1 \mathrm{~B}}-\beta_{3}$ complexation during development. $A$, Immunoprecipitation of $\left[{ }^{125} \mathrm{I}\right] \omega$-CgTx-labeled N-VDCCs by anti- $\beta_{3}$ antibodies. Hippocampal membranes from rats at various ages were labeled with $\left[{ }^{125} \mathrm{I}\right] \omega$-CgTx, solubilized with digitonin, and immunoprecipitated by anti- $\beta_{3}$ antibodies, and then the radioactivity was counted (see Materials and Methods). The specific radioactivity in the immunoprecipitates is shown as the mean $\pm \operatorname{SEM}(n=3)$. The inset shows the ratio of the $\left[{ }^{125} \mathrm{I}\right] \omega$-CgTx radioactivity in the $\beta_{3}$ immunoprecipitates to that in the solubilizates after normalizing the respective data to values obtained at P10. The lines of best fit and 95\% confidence limits, corresponding to the linear equation $y=b_{0}+b_{1} \cdot x$ (in which $y$ and $x$ correspond to the ratio and the days postnatal, respectively), are shown as solid and dotted lines, respectively. The corresponding regression coefficients $b_{0}$ and $b_{1}$ were 0.94 and -0.003 , respectively. $B$, Immunoprecipitation of $\beta_{3}$ subunits by anti- $\alpha_{18}$ antibodies. Hippocampal membranes from rats at E18, P1.5, P4, P10, and $\mathrm{P} 25$ (lanes $a-e$, respectively) were labeled with $\left[{ }^{125} \mathrm{I}\right] \omega-\mathrm{CgTx}$, solubilized with digitonin, and immunoprecipitated by biotinylated anti- $\alpha_{1}$ antibodies on streptavidin-agarose (see Materials and Methods). The level of $\beta_{3}$ in the immunoprecipitates was assayed by immunoblotting with digoxygenylated anti- $\beta_{3}$ antibodies and quantified densitometrically (axis, right). The concentration of $\left[{ }^{125} \mathrm{I}\right] \omega$-CgTx binding sites at the corresponding ages was determined from the radioactivity in the immunoprecipitates before electrophoresis (axis, left). The ratio of the $\beta_{3}$ subunits determined densitometrically to the $\left[{ }^{125} \mathrm{I}\right] \omega$-CgTx radioactivity in the $\alpha_{1 \mathrm{~B}}$ immunoprecipitates is shown in the inset after the respective data had been normalized to the values obtained at P10. The lines of best fit and 95\% confidence limits, determined by linear regression, are shown as solid and dotted lines, respectively, and the corresponding regression coefficients (calculated as above) were 0.90 for $b_{0}$ and 0.006 for $b_{1}$, respectively. 


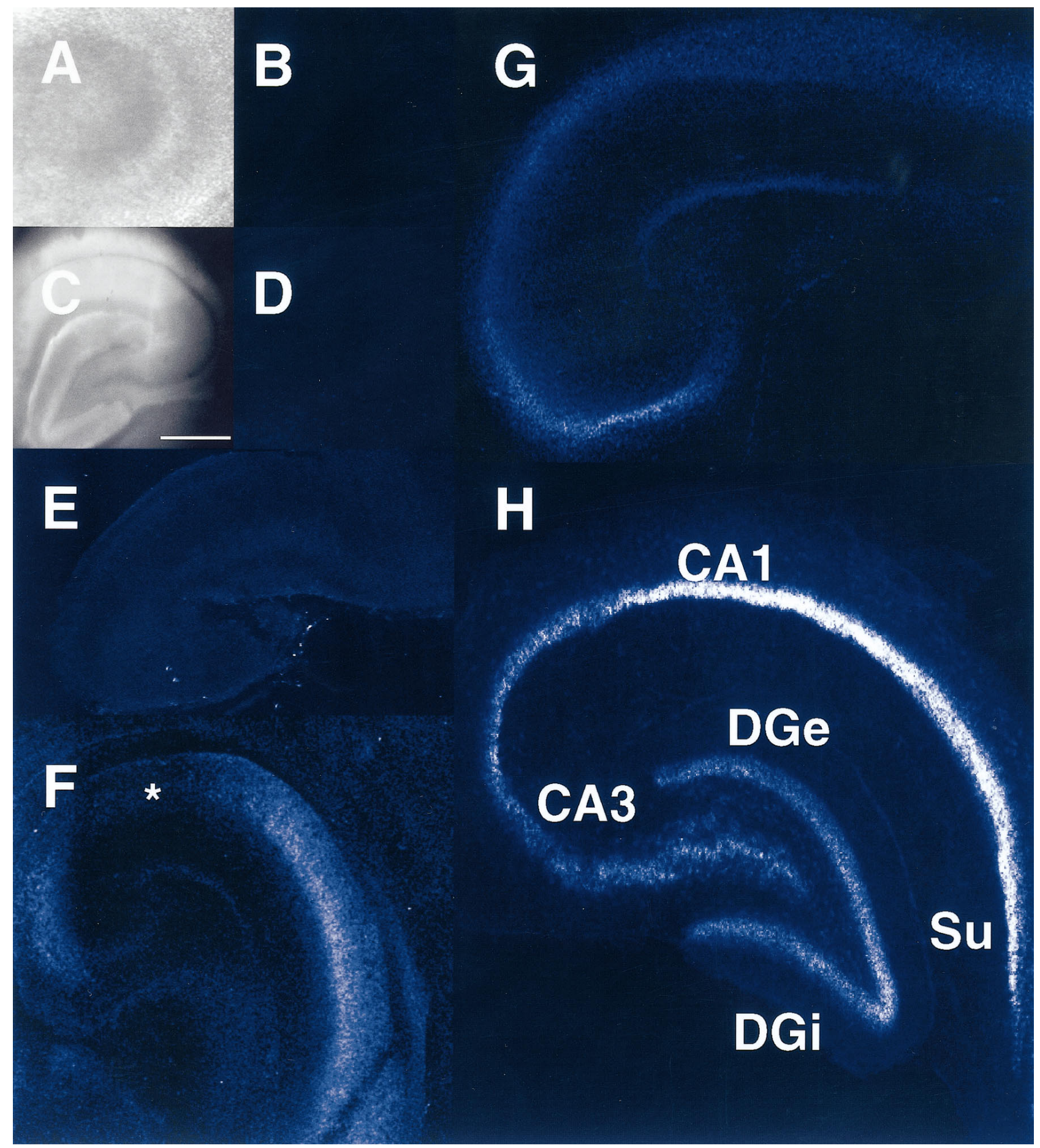

Figure 7. Distribution of N-VDCCs in the developing rat hippocampus, as determined by Fl- $\omega$-CgTx labeling. Hippocampi were sectioned, labeled with Fl- $\omega$-CgTx, and imaged at low power by confocal fluorescence microscopy, as described (see Materials and Methods). $A-D$, Control experiments reveal lack of fluorescence $(B, D)$ in hippocampal slices pretreated with $\omega$-CgTx before labeling with Fl- $\omega$-CgTx at both $\mathrm{P} 0(A, B)$ and $\mathrm{P} 40(C, D)$. $A$ and $C$ show phase micrographs corresponding to the slices in $B$ and $D$. Scale bar in $C, 500 \mu \mathrm{m}$. $E-H$, Distribution of fluorescence in hippocampal slices labeled with Fl- $\omega$-CgTx. $E$, Hippocampus at E19; note absence of marked staining. F, Hippocampus at P0; note relative absence of staining in subfields CA1-CA2 (asterisk) and the dentate gyrus, as compared with CA3-CA4 and the subiculum $(\mathrm{Su})$. $G$, At day 4, labeling is detected in the somata and dendrites of all subfields, except the internal granule cell layer of the dentate gyrus $(D G i)$. $H$, Labeling of adult hippocampus by Fl- $\omega$-CgTx is now evident in all fields and is consistently higher on the somata than in the dendrites. DGe, Dentate gyrus. All measurements were replicated in at least five separate experiments.

between $\mathrm{P} 0$ and $\mathrm{P} 16$, in agreement with our $\left[{ }^{125} \mathrm{I}\right] \omega$-CgTx binding data. Nevertheless, N-VDCC expression is not uniform throughout the hippocampus but occurs in subfields CA3-CA4 and the subiculum before dentate gyrus and CA1-CA2. In all regions $\mathrm{N}-\mathrm{VDCC}$ appear on somata before dendrites.
Numerous studies have shown that bona fide VDCC function depends on the coexpression of $\alpha_{1}, \alpha_{2} / \delta$, and $\beta$ subunits (Brust et al., 1993; Stea et al., 1993; Isom et al., 1994; Olcese et al., 1994; Gurnett et al., 1996). The presence of $\alpha_{1}, \alpha_{2} / \delta$, and $\beta_{3}$ subunits in the prenatal hippocampus argues that embryonic N-VDCCs may 
be functionally competent; nevertheless, the levels of both $\alpha_{1 \mathrm{~B}}$ and $\beta_{3}$ subunits are very low ( $<5 \%$ of adult levels) at E18. In contrast, $\alpha_{2} / \delta$ subunits are much more prevalent at E18 (45\% of adult levels) than either $\alpha_{1 \mathrm{~B}}$ or $\beta_{3}$ subunits, and their expression is phasic. These data presumably reflect complexation of the $\alpha_{2} / \delta$ subunits with other non-N-type VDCCs (Dunlap et al., 1995; Liu et al., 1996a), the expression patterns of which are tailored to the developing prenatal hippocampus. Likewise, the more sustained expression of $\beta_{3}$, as compared with $\alpha_{1 \mathrm{~B}}$, subunits at later stages of development is rationalized most simply via the association of the $\beta_{3}$ subunits with other non- $\alpha_{1 \mathrm{~B}}$ subunits, notably $\alpha_{1 \mathrm{~A}}$, known to be expressed in adult brain (Liu et al., 1996a). Of greater interest is whether the degree of $\alpha_{1 \mathrm{~B}}-\beta_{3}$ complexation changes in development. Changes in heteromer composition in development are well documented (Sheng et al., 1994; Murray et al., 1995) and would be especially significant for VDCCs because the $\alpha_{1 \mathrm{~B}}-\beta$ subunit interaction is known to be promiscuous (De Waard et al., 1995; Liu et al., 1996a; Scott et al., 1996) and can be displaced by interaction with G-proteins (De Waard et al., 1997; Zamponi et al., 1997). Moreover, multiple $\beta$ subunits can exist in individual cell types (Liu et al., 1996b), and different $\beta$ subunits confer discrete kinetic characteristics to VDCCs (De Waard and Campbell, 1995). Nevertheless, our immunoprecipitation data clearly indicate that the ratio of $\alpha_{1 \mathrm{~B}}: \beta_{3}$ subunits remains constant between E18 and P40 despite changes in the absolute levels of the $\alpha_{1 \mathrm{~B}}-\beta_{3}$ complexes. The enhanced expression of N-VDCCs without accompanying changes in subunit composition that we observed in brain also has been seen during NGF-induced differentiation of PC12 cells in culture (Liu et al., 1996b). Together, these data suggest that N-VDCC subunit expression and assembly are highly coordinated.

Throughout, we failed to detect major $(>5 \%)$ excursions from the anticipated sizes of the $\alpha_{1 \mathrm{~B}}, \alpha_{2} / \delta$, or $\beta_{3}$ subunits, indicating that they do not undergo extensive processing during development. Occasionally, minor bands were seen for $\alpha_{1 \mathrm{~B}}$, suggesting that other variants may exist besides the $220 \mathrm{kDa}$ subunits reported previously (Westenbroek et al., 1992; Hell et al., 1994) or that $\alpha_{1 \mathrm{~B}}$ subunits undergo extensive differential post-translational modifications or proteolysis. The lower size of the $\alpha_{1 \mathrm{~B}}$ subunits determined by SDS-PAGE, as compared with the $262 \mathrm{kDa}$ predicted from the corresponding cDNA (Dubel et al., 1992), is typical of $\alpha_{1 \mathrm{~B}}$ (Westenbroek et al., 1992) and other $\alpha_{1}$ VDCC subunits and has been attributed to anomalous migration in $5 \%$ gels (Hell et al., 1993).

Particularly intriguing is our observation that the ease of solubilization of N-VDCCs decreases between E18 and P10, presumably via an increased association of N-VDCCs with detergent-intractable components, especially those of the neuronal cytoskeleton. An interaction of N-VDCCs with the cytoskeleton is supported by the polarized distribution (Jones et al., 1989; Westenbroek et al., 1992; Mills et al., 1994; Christie et al., 1995) and the immobility of $>70 \%$ (Jones et al., 1989) of N-VDCCs in mature hippocampal neurons and by the fact that the first postnatal week is a major phase for maturation of the neuronal cytoskeleton (Burgoyne, 1991).
To resolve only the surface N-VDCCs, we used high-resolution imaging of slices labeled with a selective fluorescent analog of $\omega$-CgTx (Mills et al., 1994). The validity of such CgTx-based approaches (Jones et al., 1989; Robitaille et al., 1990; Cohen et al., 1991; Komura and Rakic, 1992; Filloux et al., 1994; Haydon et al., 1994; Mills et al., 1994) is substantiated by the similar temporal expression patterns of the $220 \mathrm{kDa} \alpha_{1 \mathrm{~B}}$ subunit, $\omega-\mathrm{CgTx}$ binding sites, and overall Fl- $\omega$-CgTx labeling. Our study also agrees with that of Filloux et al. (1994), who used $\left[{ }^{125} \mathrm{I}\right] \omega-\mathrm{CgTx}$ autoradiography to explore N-VDCC ontogeny in the rat brain; however, we did not detect the developmental increase in $\left[{ }^{125} \mathrm{I}\right] \omega$ CgTx affinity reported by these authors. More significantly, the ontogeny of Fl- $\omega$-CgTx labeling is very similar to that obtained via in situ hybridization (Tanaka et al., 1995) where, from E18 onward, both $\alpha_{1 \mathrm{~B}}$ and $\beta_{3}$ mRNAs are evident in all cell body layers throughout the hippocampal formation. The only real discrepancy concerns the lower expression of Fl- $\omega$-CgTx labeling in CA1-CA2 relative to adjacent regions before $\mathrm{P} 7$. The simplest explanation is that neurons in discrete hippocampal subfields translate and insert N-VDCCs differentially at the nerve surface. However, disparities between Fl- $\omega$-CgTx labeling and mRNA expression also could reflect staining of N-VDCCs trafficked to presynaptic terminals impinging on the somata rather than to $\mathrm{N}-\mathrm{VDCC}$ made by translation in the postsynaptic cell. However, such an explanation would require targeting of N-VDCCs to axon terminals before their expression on somata-a result that is inconsistent with our observation that N-VDCCs are expressed initially on cell bodies.

The initial surface expression of N-VDCCs in the soma before the distal dendrites is intriguing but has been seen for other ion channels (Strichartz et al., 1984; Nicola et al., 1992; MaleticSavatic, 1995). Previously, it has been postulated that the transport of proteins into neurites arises via their initial expression at the soma surface and subsequent diffusion in the plane of the membrane to more peripheral regions (Small et al., 1984). However, the absence of a clear somatodendritic (or dendritic) gradient of N-VDCC expression, despite the presence of dendrites in P7 or adult neurons (Westenbroek et al., 1992; Mills et al., 1994), indicates that VDCCs also are inserted (and immobilized) directly into the dendritic membrane. Thus, expression of $\mathrm{N}-\mathrm{VDCC}$ in the neurites may proceed only after these regions are mature enough to support the appropriate trafficking, insertion, and immobilization mechanisms.

The possible role of N-VDCC expression in the development of the hippocampus is especially significant. In the rat, formation of the hippocampus begins at E14 (Altman and Bayer, 1990a-c; Jacobson, 1991). Neuroblasts, which have arisen through proliferation in the neuroepithelium, migrate to specified positions, settle, and elaborate axons and dendrites. In CA1-CA4 such events are complete by birth (Altman and Bayer, 1990a,b), but in dentate gyrus they continue for several weeks postnatally (Altman and Bayer, 1990c). However, although CA3 cells are generated earlier than CA1 cells, they take longer to settle in stratum pyramidale, reflecting a subicular-to-dentate morphogenetic gradient complete by E22 (Altman and Bayer, 1990b). Thus, the

Figure 8. Comparative distributions of Fl- $\omega-\mathrm{CgTx}$ labeling and CA1 neurons identified by filling with the intracellular dye Lucifer yellow. $A$, Hippocampal CA1 neurons at P2 filled with Lucifer yellow show extensive arborization (arrows) but weak staining with Fl- $\omega$-CgTx (inset, asterisk). In contrast to CA1, staining with Fl- $\omega$-CgTx is much stronger in the adjacent subiculum (inset, arrow). B, Direct comparison of the distributions of Fl- $\omega$-CgTx labeling and CA1 neurons identified by Lucifer yellow filling (arrows) at P3. Note the much weaker staining of the CA1 subfield neurons, as compared with those in the cingulate cortex (top left). C, Fl- $\omega$-CgTx labeling in P7 CA1 neurons. Note the strong staining of the (Figure legend continues) 


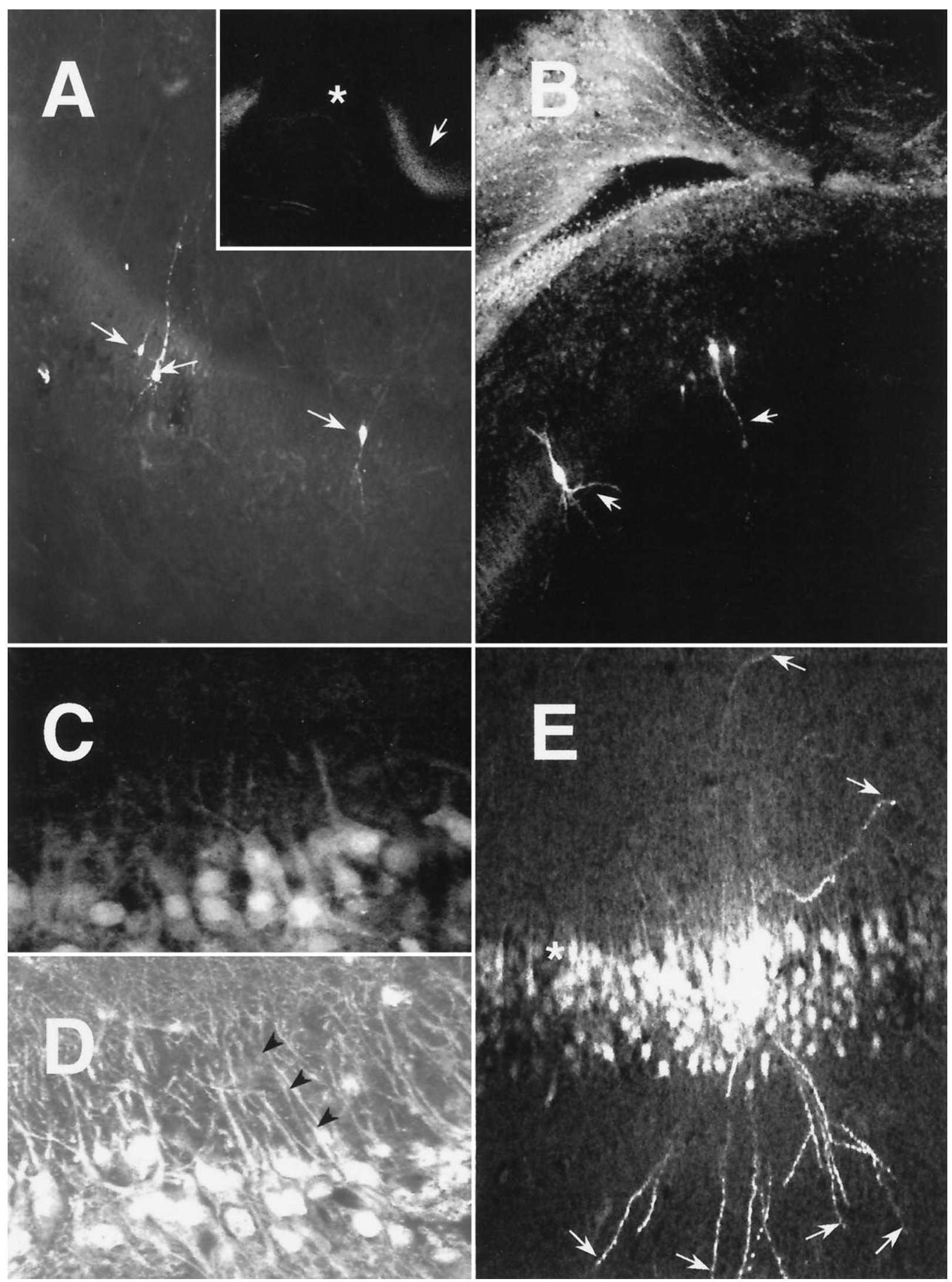

somata and the very proximal dendritic regions and the sharp decline in labeling that occur within a few soma diameters from the cell body. $D$, Fl- $\omega$-CgTx labeling in adult CA1 neurons. Note that the staining, while often punctate, is sustained for distances corresponding to several soma diameters on dendrites emanating from identifiable somata (arrowheads) and pervades the dendritic arbor. $E$, At high magnification, Lucifer filling of P7 CA1 neurons reveals extensive dendritic arborization and stains even the most distal dendritic regions (arrows), whereas the Fl- $\omega$-CgTx labeling is restricted to somata and very proximal dendrites (asterisk), as in $C$. 
sequence of N-VDCC surface expression seems to parallel the postmitotic age of the neurons rather than their time of settling in stratum pyramidale. The absence of $\alpha_{1 \mathrm{~B}}$ subunits in neurogenic zones, but their prenatal expression elsewhere, is compatible with a role for N-VDCCs in migration, as proposed for cerebellar neurons (Komura and Rakic, 1992). However, the perinatal levels of $\alpha_{1 \mathrm{~B}}$ are only $2-5 \%$ of those found in adult. Thus if N-VDCCs indeed do facilitate migration, relatively few channels are needed, or few cells are migrating at any one instant. Most N-VDCCs appear within the early postnatal period, consonant with reported increases in $\mathrm{HVA} \mathrm{Ca}{ }^{2+}$ currents, such as those generated by N-VDCCs in culture (Yaari et al., 1987; Scholz and Miller, 1995). This period is marked initially by dendritic arborization and gliogenesis, but the event that most closely defines N-VDCC expression is synaptogenesis, the bulk of which occurs in the first few weeks after birth (Jacobson, 1991). An intimate relationship between N-VDCC expression and synaptogenesis is supported by changes in $\omega$-CgTx binding in mouse brain growth cone particles (Vigers and Pfenninger, 1991). Certainly, the pattern of expression of N-VDCCs, unlike several other voltage-gated ion channels (Yaari et al., 1987; Maletic-Savatic et al., 1995; Scholz and Miller, 1995), is remarkably similar to that of other proteins implicated in synaptic function (Burgin et al., 1990; Bahn et al., 1994; Lomeli et al., 1994; Melloni et al., 1994; Sheng et al., 1994). Enhanced expression of N-VDCCs during synaptogenesis agrees well with their role in neurotransmitter release (Dunlap et al., 1995; Scholz and Miller, 1995). Although the role of N-VDCCs in neurotransmission is shared with other VDCCs in adult neurons (Wheeler et al., 1994; Scholz and Miller, 1995), two lines of evidence suggest that N-VDCCs may be especially significant in the immature hippocampus. First, neurotransmission in developing cultures is dominated initially by N-VDCCs, the role of which declines as their task becomes shared by P/Q-VDCCs (Scholz and Miller, 1995). Second, the efficacy of CA1 synapses is reported to be high [release probability $\left(P_{\mathrm{r}}\right)$ close to unity] in very young (P4-P6) hippocampi but diminishes to a lower level $\left(P_{\mathrm{r}}\right.$ $<0.5$ ) with maturation (Bolshakov and Siegelbaum, 1995). A purely presynaptic role for N-VDCCs is probably unlikely, however, because N-VDCCs also are found on hippocampal dendrites (Jones et al., 1989; Westenbroek et al., 1992; Mills et al., 1994; Christie et al., 1995) and their spines (Mills et al., 1994). Although the functional contribution such postsynaptic N-VDCCs make is unclear (Mills et al., 1994; Elliott et al., 1995), one plausible role is to direct afferent axons to discrete synapses. Such a role also may explain the shift in synapses from dendritic shafts to spines that is seen between P7 and P15 (Harris et al., 1992).

Several physiological correlates of hippocampal maturation emerge within the same time window as N-VDCC expression in the immature hippocampus. Toward the end of the first postnatal week CA1 pyramidal cells begin to exhibit adult electrophysiological characteristics and population spiking (Bekenstein and Lothman, 1991; Bolshakov and Siegelbaum, 1995). Remarkably, this phase coincides with our initial detection of N-VDCCs in CA1 and the arrival of the commissural and perforant fibers to CA1 and dentate gyrus, respectively (Bekenstein and Lothman, 1991). The early expression of N-VDCCs in the lateral blade of the dentate gyrus merits attention because the lateral perforant pathway relays primarily olfactory inputs, whereas the medial pathway relays presubicular and nonolfactory inputs from the entorhinal cortex (Shepherd, 1990). Marked changes in activitydependent plasticity, notably paired pulse facilitation (PPF) and long-term potentiation (LTP) and depression (LTD), also occur in the early postnatal period. LTD is greatest before P14 (Dudek and Bear, 1993) whereas LTP reaches adult levels at $\sim$ P14 (Dudek and Bear, 1993). Although the relative contribution of pre- and postsynaptic mechanisms to such events is controversial (Kullmann and Siegelbaum, 1995), the absence of PPF and LTP, but not LTD, at CA3-CA1 synapses in P4-P8 animals can be rationalized by their high-release probability $\left(P_{\mathrm{r}} 0.9\right)$ (Bolshakov and Siegelbaum, 1995). Thus, N-VDCCs may be of central importance to synaptic plasticity simply by virtue of their predominant role in juvenile transmitter release (Scholz and Miller, 1995).

\section{REFERENCES}

Altman J, Bayer SA (1990a) Mosaic organization of the hippocampal neuroepithelium and the multiple germinal sources of dentate granule cells. J Comp Neurol 301:325-342.

Altman J, Bayer SA (1990b) Prolonged sojourn of developing pyramidal cells in the intermediate zone of the hippocampus and their settling in the stratum pyramidale. J Comp Neurol 301:343-364.

Altman J, Bayer SA (1990c) Migration and distribution of two populations of hippocampal granule cell precursors during the perinatal and postnatal periods. J Comp Neurol 301:365-381.

Bading H, Ginty DD, Greenberg ME (1993) Regulation of gene expression in hippocampal neurons by distinct calcium signaling pathways. Science 260:181-186.

Bahn S, Volk B, Wisden W (1994) Kainate receptor gene expression in the developing rat brain. J Neurosci 14:5525-5547.

Bekenstein JW, Lothman EW (1991) A comparison of the ontogeny of excitatory and inhibitory neurotransmission in the CA1 region and dentate gyrus of the rat hippocampal formation. Dev Brain Res 63:237-243.

Bolshakov VY, Siegelbaum SA (1995) Regulation of hippocampal transmitter release during development and long-term potentiation. Science 269:1730-1734.

Brust PF, Simerson S, McCue AF, Deal CR, Schoonmaker S, Williams ME, Velicelebi G, Johnson EC, Harpold MM, Ellis SB (1993) Human neuronal voltage-dependent calcium channels: studies on subunit structure and role in channel assembly. Neuropharmacology 32:1089-1102.

Burgin KE, Waxham MN, Rickling S, Westgate SA, Mobley WA, Kelly PT (1990) In situ hybridization histochemistry of $\mathrm{Ca}^{2+} /$ calmodulindependent protein kinase in developing rat brain. J Neurosci 10:1788-1798.

Burgoyne RD (1991) The neuronal cytoskeleton. New York: Wiley-Liss.

Castellano A, Wei X, Birnbaumer L, Perez-Reyes E (1993) Cloning and expression of a neuronal calcium channel $\beta$ subunit. J Biol Chem 268:12359-12366.

Christie BR, Eliot LS, Ito K, Miyakawa H, Johnston D (1995) Different $\mathrm{Ca}^{2+}$ channels in soma and dendrites of hippocampal pyramidal neurons mediate spike-induced $\mathrm{Ca}^{2+}$ influx. J Neurophysiol 73:2553-2557.

Cohen MW, Jones OT, Angelides KJ (1991) Distribution of $\mathrm{Ca}^{2+}$ channels on frog motor nerve terminals revealed by fluorescent $\omega$-conotoxin. J Neurosci 11:1032-1039.

Cruz LJ, Olivera BM (1986) Calcium channel antagonists: $\omega$-conotoxin defines a new high-affinity state. J Biol Chem 261:6230-6233.

De Waard M, Campbell KP (1995) Subunit regulation of the neuronal $\alpha_{1 \mathrm{~A}} \mathrm{Ca}^{2+}$ channel expressed in Xenopus oocytes. J Physiol (Lond) 485:619-634.

De Waard M, Witcher DR, Pragnell M, Liu H, Campbell KP (1995) Properties of the $\alpha_{1}-\beta$ anchoring site in voltage-dependent $\mathrm{Ca}^{2+}$ channels. J Biol Chem 270:12056-12064.

De Waard M, Liu H, Walker D, Scott VES, Gurnett CA, Campbell KP (1997) Direct binding of G-protein $\beta \gamma$ complex to voltage-dependent calcium channels. Nature 385:446-450.

Dubel SJ, Starr TVB, Hell J, Ahlijanian MK, Enyeart JJ, Catterall WA, Snutch TP (1992) Molecular cloning of the $\alpha 1$ subunit of an $\omega$-conotoxin-sensitive calcium channel. Proc Natl Acad Sci USA 89:5058-5062.

Dudek SM, Bear MF (1993) Bidirectional long-term modification of synaptic effectiveness in the adult and immature hippocampus. J Neurosci 13:2910-2918.

Dunlap K, Luebke JI, Turner TJ (1995) Exocytotic $\mathrm{Ca}^{2+}$ channels in mammalian central neurons. Trends Neurosci 18:89-98. 
Elliott EM, Malouf AT, Catterall WA (1995) Role of calcium channel subtypes in calcium transients in hippocampal CA3 neurons. J Neurosci 15:6433-6444.

Filloux F, Schapper A, Scott R, Olivera BM, McIntosh JM (1994) Complex patterns of $\left[{ }^{125} \mathrm{I}\right] \omega$-conotoxin GV IA binding site expression during postnatal rat brain development. Dev Brain Res 78:131-136.

Fujita Y, Mynlieff M, Dirksen RT, Kim M, Niidome T, Nakai J, Friedrich T, Iwabe N, Miyata T, Furuichi T, Furutama D, Mikoshiba K, Mori Y, Beam KG (1993) Primary structure and functional expression of the $\omega$-conotoxin-sensitive $\mathrm{N}$-type calcium channel from rabbit brain. Neuron 10:585-598.

Gurnett CA, De Waard M, Campbell KP (1996) Dual function of the voltage-dependent $\mathrm{Ca}^{2+}$ channel $\alpha_{2} \delta$ subunit in current stimulation and subunit interaction. Neuron 16:431-440.

Harris KM, Jensen FE, Tsao B (1992) Three-dimensional structure of dendritic spines and synapses in rat hippocampus (CA1) at postnatal day 15 and adult ages: implications for the maturation of synaptic physiology and long-term potentiation. J Neurosci 12:2685-2705.

Haydon PG, Henderson E, Stanley EF (1994) Localization of individual calcium channels at the release face of a presynaptic nerve terminal. Neuron 13:1275-1280.

Hell JW, Westenbroek RE, Warner C, Ahlijanian MK, Prystay W, Gilbert MM, Snutch TP, Catterall WA (1993) Identification and differential subcellular localization of the neuronal class C and class D L-type calcium channel $\alpha 1$ subunits. J Cell Biol 123:949-962.

Hell JW, Appleyard SM, Yokoyama CT, Warner C, Catterall WA (1994) Differential phosphorylation of two size forms of the N-type calcium channel $\alpha 1$ subunit which have different $\mathrm{COOH}$ termini. J Biol Chem 269:7390-7396.

Hofmann F, Biel M, Flockerzi V (1994) Molecular basis for $\mathrm{Ca}^{2+}$ channel diversity. Annu Rev Neurosci 17:399-418.

Isom LL, De Jongh KS, Catterall WA (1994) Auxiliary subunits of voltage-gated channels. Neuron 12:1183-1194.

Jacobson M (1991) Developmental neurobiology, 3rd Ed. New York: Plenum.

Johnson Jr EM, Deckwerth TL (1993) Molecular mechanisms of developmental neuronal death. Annu Rev Neurosci 16:31-46.

Jones OT, So AP (1993) Preparation and characterization of biotinylated analogs of $\omega$-conotoxin. Anal Biochem 214:227-232.

Jones OT, Kunze DL, Angelides KJ (1989) Localization and mobility of $\omega$-conotoxin-sensitive $\mathrm{Ca}^{2+}$ channels in hippocampal CA1 neurons. Science 244:1189-1193.

Kim H-L, Kim H, Lee P, King RG, Chin H (1992) Rat brain expresses an alternatively spliced form of the dihydropyridinesensitive L-type calcium channel $\alpha 2$ subunit. Proc Natl Acad Sci USA 89:3251-3255.

Komura H, Rakic P (1992) Selective role of N-type calcium channels in neuronal migration. Science 257:806-809.

Kullmann DM, Siegelbaum SA (1995) The site of expression of NMDA receptor-dependent LTP: new fuel for an old fire. Neuron 15:997-1002.

Laemmli UK (1970) Cleavage of structural proteins during the assembly of the head of bacteriophage T4. Nature 227:680-685.

Leveque C, El Far O, Martin-Martout N, Sato K, Kato R, Takahashi M, Seagar MJ (1994) Purification of the N-type calcium channel associated with syntaxin and synaptotagmin. A complex implicated in synaptic vesicle exocytosis. J Biol Chem 269:6306-6312.

Liu H, De Waard M, Scott VES, Gurnett CA, Lennon VA, Campbell KP (1996a) Identification of three subunits of the high-affinity $\omega$-conotoxin MVIIC-sensitive $\mathrm{Ca}^{2+}$ channel. J Biol Chem 271:13804-13810.

Liu H, Felix R, Gurnett CA, De Waard M, Witcher DR, Campbell KP (1996b) Expression and subunit interaction of voltage-dependent $\mathrm{Ca}^{2+}$ channels in PC12 cells. J Neurosci 16:7557-7565.

Llinás RR (1988) The intrinsic electrophysiological properties of mammalian neurons: insights into central nervous system function. Science 242:1654-1664.

Llinás RR, Sugimori M (1979) Calcium conductances in Purkinje cell dendrites: their role in development and integration. Prog Brain Res 51:323-334.

Lomeli H, Mosbacher J, Melcher T, Hoger T, Geiger JRP, Kuner T, Monyer H, Higuchi M, Bach A, Seeburg PH (1994) Control of kinetic properties of AMPA receptor channels by nuclear RNA editing. Science 266:1709-1713.

Maletic-Savatic M, Lenn NJ, Trimmer JS (1995) Differential spatiotemporal expression of $\mathrm{K}^{+}$channel polypetides in rat hippocampal neurons developing in situ and in vitro. J Neurosci 15:3840-3851.
Melloni RH, Apostolides PJ, Hamos JE, DeGennaro LJ (1994) Dynamics of synapsin I gene expression during the establishment and restoration of functional synapses in the rat hippocampus. Neuroscience 58:683-703.

Mills LR, Kater SB (1990) Neuron-specific and state-specific differences in calcium homeostasis regulate the generation and degeneration of neuronal architecture. Neuron 4:149-163.

Mills LR, Niesen CE, So AP, Carlen PL, Spigelman I, Jones OT (1994) $\mathrm{N}$-type $\mathrm{Ca}^{2+}$ channels are located on somata, dendrites, and a subpopulation of dendritic spines on live hippocampal pyramidal neurons. J Neurosci 14:6815-6824.

Mori Y, Friedrich T, Kim M, Mikami A, Nakai J, Ruth P, Bosse E, Hofmann F, Flockerzi V, Furuichi T, Tikoshiba K, Imoto K, Tanabe T, Numa S (1991) Primary structure and functional expression from complementary DNA of a brain calcium channel. Nature 350:398-402.

Murray N, Zheng YC, Mandel G, Brehm P, Bolinger R, Reuer Q, Kullberg R (1995) A single site in the epsilon subunit is responsible for the change in ACh receptor channel conductance during skeletal muscle development. Neuron 14:865-870.

Nicola M-A, Becker C-M, Triller A (1992) Development of glycine receptor alpha subunit in cultivated rat spinal neurons: an immunocytochemical study. Neurosci Lett 138:173-178.

Olcese R, Qin N, Schneider T, Neely A, Wei X, Stefani E, Birnbaumer L (1994) The amino terminus of a calcium channel $\beta$ subunit sets rates of channel inactivation independently of the subunit's effect on activation. Neuron 13:1433-1438.

Peacock JH, Walker CR (1983) Development of calcium action potentials in mouse hippocampal cell cultures. Dev Brain Res 8:39-52.

Reece LJ, Schwartzkroin PA (1991) Effects of cholinergic agonists on immature rat hippocampal neurons. Dev Brain Res 60:29-42.

Robitaille R, Adler EM, Charlton MP (1990) Strategic location of calcium channels at transmitter release sites of frog neuromuscular synapses. Neuron 5:773-779.

Sakamoto J, Campbell KP (1991) A monoclonal antibody to the $\beta$ subunit of the skeletal muscle dihydropyridine receptor immunoprecipitates the brain $\omega$-conotoxin GVIA receptor. J Biol Chem 266: 18914-18919.

Scholz KP, Miller RJ (1995) Developmental changes in presynaptic calcium channels coupled to glutamate release in cultured rat hippocampal neurons. J Neurosci 15:4612-4617.

Scott VES, De Waard M, Liu H, Gurnett CA, Venzke DP, Lennon VA, Campbell KP (1996) $\beta$-Subunit heterogeneity in N-type $\mathrm{Ca}^{2+}$ channels. J Biol Chem 271:3207-3212.

Sheng M, Cummings J, Roldan LA, Jan YN, Jan LY (1994) Changing subunit composition of heteromeric NMDA receptors during development of rat cortex. Nature 368:144-147.

Shepherd GM (1990) The synaptic organization of the brain. New York: Oxford UP.

Small RK, Blank M, Ghez R, Pfenninger KH (1984) Components of the plasma membrane of growing axons. II. Diff usion of membrane protein complexes. J Cell Biol 98:1434-1443.

Spitzer NC, Xiaonan G, Olsen E (1994) Action potentials, calcium transients, and the control of differentiation of excitable cells. Curr Opin Neurobiol 4:70-77.

Stea A, Dubel SJ, Pragnell M, Leonard JP, Campbell KP, Snutch TP (1993) A $\beta$-subunit normalizes the electrophysiological properties of a cloned N-type calcium channel. Neuropharmacology 32:1103-1116.

Stea A, Tomlinson WJ, Soong TW, Bourinet E, Dubel SJ, Vincent SR, Snutch TP (1994) The localization and functional properties of a rat brain $\alpha_{1 \mathrm{~A}}$ calcium channel reflect similarities to neuronal Q- and P-type channels. Proc Natl Acad Sci USA 91:10576-10580.

Strichartz GR, Small RK, Pfenninger KH (1984) Components of the plasma membrane of growing axons. III. Saxitoxin binding to sodium channels. J Cell Biol 98:1444-1452.

Tanaka O, Sakagami H, Kondo H (1995) Localization of mRNAs of voltage-dependent $\mathrm{Ca}^{2+}$ channels: four subtypes of $\alpha 1$ - and $\beta$ - subunits in developing and mature rat brain. Mol Brain Res 30:1-16.

Towbin H, Staehelin T, Gordon J (1979) Electrophoretic transfer of proteins from polyacrylamide gels to nitrocellulose sheets: procedure and some applications. Proc Natl Acad Sci USA 76:4350-4354.

Vigers AJ, Pfenninger KH (1991) N-type and L-type calcium channels are present in nerve growth cones. Numbers increase on synaptogenesis. Dev Brain Res 60:197-203.

Wagner J, Snowman AM, Biswas A, Olivera BM, Snyder SH (1988) 
$\omega$-Conotoxin GVIA binding to a high-affinity receptor in brain: characterization, calcium sensitivity, and solubilization. $\mathrm{J}$ Neurosci $8: 3354-3359$.

Westenbroek RE, Ahlijanian MK, Catterall WA (1990) Clustering of L-type calcium channels at the base of major dendrites in hippocampal pyramidal neurones. Nature 347:281-284.

Westenbroek R, Hell JW, Warner C, Dubel SJ, Snutch TP, Catterall WA (1992) Biochemical properties and subcellular distribution of an N-type calcium channel $\alpha 1$ subunit. Neuron 9:1099-1115.

Westenbroek RE, Sakurai T, Elliott EM, Hell JW, Starr TVB, Snutch TP, Catterall WA (1995) Immunochemical identification and subcellular distribution of the $\alpha_{1 \mathrm{~A}}$ subunits of brain calcium channels. J Neurosci 15:6403-6418.

Wheeler DB, Randall A, Tsien RW (1994) Roles of N-type and Q-type $\mathrm{Ca}^{2+}$ channels in supporting hippocampal synaptic transmission. Science 264:107-111.

Williams ME, Brust PF, Feldman DH, Patthi S, Simerson S, Maroufi A,
McCue AF, Velicelebi G, Ellis SB, Harpold MM (1992a) Structure and functional expression of an $\omega$-conotoxin-sensitive human N-type calcium channel. Science 257:389-395.

Williams ME, Feldman DH, McCue AF, Brenner R, Velicelebi G, Ellis SB, Harpold MM (1992b) Structure and functional expression of $\alpha 1$, $\alpha 2$, and $\beta$ subunits of a novel human neuronal calcium channel subtype. Neuron 8:71-84.

Witcher DR, De Waard M, Sakamoto J, Franzini-Armstrong C, Pragnell M, Kahl SD, Campbell KP (1993) Subunit identification and reconstitution of the N-type $\mathrm{Ca}^{2+}$ channel complex purified from brain. Science 261:486-489.

Yaari Y, Hamon B, Lux HD (1987) Development of two types of calcium channels in cultured mammalian hippocampal neurons. Science 235:680-682.

Zamponi GW, Bourinet E, Nelson D, Nargeot J, Snutch TP (1997) Crosstalk between G-proteins and protein kinase $\mathrm{C}$ mediated by the calcium channel $\alpha_{1}$ subunit. Nature 385:442-446. 